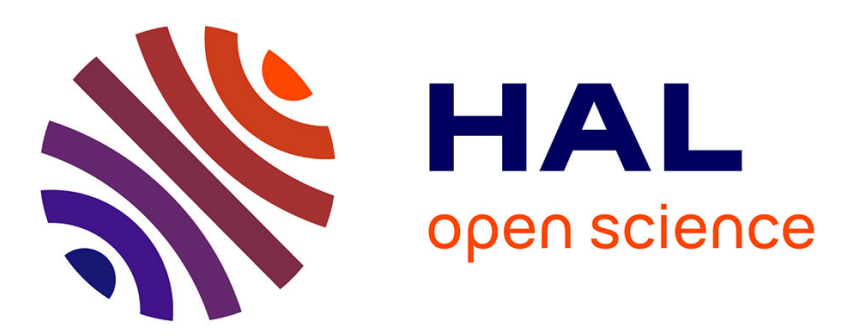

\title{
Exchange rate policy and external vulnerabilities in Sub-Saharan Africa: nominal, real or mixed targeting?
}

Fadia Al Hajj, Gilles Dufrénot, Benjamin Keddad

\section{To cite this version:}

Fadia Al Hajj, Gilles Dufrénot, Benjamin Keddad. Exchange rate policy and external vulnerabilities in Sub-Saharan Africa: nominal, real or mixed targeting?. Applied Economics, 2021, 53 (3), pp.380-399. 10.1080/00036846.2020.1808176 . hal-02935990

\section{HAL Id: hal-02935990 https://hal-amu.archives-ouvertes.fr/hal-02935990}

Submitted on 14 Sep 2020

HAL is a multi-disciplinary open access archive for the deposit and dissemination of scientific research documents, whether they are published or not. The documents may come from teaching and research institutions in France or abroad, or from public or private research centers.
L'archive ouverte pluridisciplinaire HAL, est destinée au dépôt et à la diffusion de documents scientifiques de niveau recherche, publiés ou non, émanant des établissements d'enseignement et de recherche français ou étrangers, des laboratoires publics ou privés. 


\title{
Exchange Rate Policy and External Vulnerabilities in Sub-Saharan Africa: Nominal, Real or Mixed Targeting?
}

\author{
Fadia Al Hajj ${ }^{1}$, Gilles Dufrénot ${ }^{1}$, Benjamin $\operatorname{Keddad}^{2, *}$ \\ Aix-Marseille Univ., CNRS, EHESS, Centrale Marseille, AMSE
}

Paris School of Business

March 2018

\begin{abstract}
This paper discusses the theoretical choice of exchange rate anchors in Sub-Saharan African countries that are facing external vulnerabilities. To reduce instability, policymakers choose among promoting external competitiveness using a real anchor, lowering the burden of external debt using a nominal anchor or using a policy mix of both anchors. We observe that these countries tend to adopt mixed anchor policies. We solve a state space model to explain the determinants of and the strategy behind this policy. We find that the choice of policy mix is a two-step strategy: First, authorities choose the degree of nominal exchange rate flexibility according to the velocity of money, trade openness, foreign debt, degree of exchange rate pass-through and exchange rate target zone. Second, authorities seek to stabilize the real exchange rate depending on the degree of trade integration with the rest of world and the degree of foreign exchange interventions. We conclude with regime-switching estimations to provide empirical evidence of how these economic fundamentals influence exchange rate policy in Sub-Saharan Africa.
\end{abstract}

Keywords: African Countries, Exchange Rate Policy, External Vulnerabilities, Regime-Switching Model JEL classification: $\mathrm{C} 32, \mathrm{~F} 31, \mathrm{O} 24$

\section{Introduction}

This paper discusses a new exchange rate policy issue in Sub-Saharan African (SSA) countries. A large number of governments have, in the past years, adopted an exchange rate anchor based on a mix between a real and a nominal target. This means that they have sought to simultaneously achieve stable real and nominal exchange rates. Few papers have discussed such a strategy, as discussions of exchange rate regimes have focused on the choice between so-called corner solutions (pure floating or fixed exchange rates) and intermediate regimes (see, for instance, Qureshi and Tsangarides , 2012; Harrigan , 2006; Husain et al. , 2005; Calvo and Mishkin , 2003). However, SSA countries face two challenges that can explain the new stylized facts that we highlight. First, they seek external competitiveness to achieve trade surpluses or

\footnotetext{
${ }^{*}$ Corresponding author

Email addresses: fadiaelhajj@hotmail.com (Fadia Al Hajj), Gilles.dufrenot@univ-amu.fr (Gilles Dufrénot), b.keddad@gmail.com (Benjamin Keddad)

${ }^{1}$ Aix-Marseille School of Economics, Aix-Marseille University, Château Lafarge, Route des Milles 13290 Aix-en-Provence, France. Tel.: 0033 (0)4 42935960 .

${ }^{2}$ PSB - Paris School of Business, 59 rue Nationale, 75013 Paris, France. Tel.: 0033 (0)1 55256948.
} 
limit their trade deficits (see UNCTAD , 2016a; Allen and Giovannetti , 2011). Second, they seek to alleviate the burden of their external debt, a significant part of which is denominated in foreign currencies (see UNCTAD, 2016b).

We propose a theoretical model that brings to light the factors that influence a policymaker's anchor strategy because many SSA countries face balance of payment crises due to high trade dependence (measured as the ratio of imports to GDP) and a lack of export diversification (see Nicita abd Rollo , 2015; Iwanow and Kirkpatrick , 2009). This imbalance has fueled the growth of foreign indebtedness. To reduce the pre-eminence of imported goods in the household's consumption basket, policymakers can adopt trade controls by either raising customs taxes or restricting imports. Alternatively, they can target the internal real exchange rate to influence the consumer's trade-off between locally produced and imported goods. Targeting the real exchange rate by controlling fluctuations in the nominal exchange rate can be achieved through various types of intermediate exchange rate regimes that lie between free floating and strict fixed exchange rate regimes: hard and soft pegs, basket pegs, target zones, crawling bands, etc. Second, we hold that policymakers are also concerned about stabilizing international reserves. Foreign reserve are needed for three purposes. One is to respond to changes in the current account balance and to stabilize the nominal exchange rate. The second is to meet the country's foreign liabilities by servicing external debt. The third motivation is to maintain access to foreign borrowing, which might be difficult in cases when reserves are depleted (credibility and reputation). Regardless of the motivation, the accumulation of foreign reserves in the African countries has served as insurance against recurrent balance of payment crises (Pina, 2015).

The determination of both the real exchange rate and foreign reserves results from consumers' decisions in the good markets (i.e., traded versus non-traded goods, demand for money and foreign borrowing) and from macroeconomic constraints such as interest rates on debt service or changes in foreign exchange rates. In this paper, we consider a deterministic version of the choice of an exchange rate regime, in the sense that we do not consider the exchange rate regime as an optimal response to a shock. Thus, the determination of the exchange rate regime is presented as the solution in a "state-space" model in which the policymaker's decision is conditioned by the state of the economy captured by the agent's decisions and the macroeconomic environment. With regards to the existing literature on the choice of exchange rate regimes, our proposed model is based upon three stands of the literature on exchange rates to which we add several new assumptions. First, the exchange rate policy is described by a target zone model, but unlike the usual literature, the exchange rate is derived neither from the assumption of monetary determination of the exchange rate nor from the assumption of purchasing power parity (PPP). We instead consider a general equilibrium-based model with tradable and non-tradable goods. This allows us to examine how monetary authority interventions in foreign exchange markets can influence the real and nominal exchange rates.

Second, unlike many papers in the literature on exchange rate regimes, we do not consider inflation or output stabilization as the final goals of monetary policy. This is not to say that their roles are negligible. We develop our argument for given levels of inflation and economic growth. We focus instead on external imbalances considering that heavy indebtedness has become crucial in many African countries. We introduce debt into our model through the consumer's budget constraint by assuming that they hold two assets: money and an IOU asset indicating how much money is owed to foreign lenders. Third, many models of currency basket pegs assume that the assumption of uncovered interest rate parity (UIP) holds, which seems inconsistent for SSA countries (see Thomas, 2012). Contrary to the usual UIP assumption, we add a premium to the interest rate incurred on foreign debt. This premium, by making debt service more costly, may limit 
indebtedness, which could in turn reduce the pressure on and the depletion of foreign reserves that are used to maintain the peg. The above assumptions are considered in a microeconomic-based model in which the real and nominal exchange rates are determined endogenously, taking into account some of the specific characteristic of the African countries: high levels of external debt, shallow domestic financial markets that do not allow capital mobility with developed countries, sharp price competition between locally produced goods and imported goods, and the existence of enclaves in some rent sectors (e.g., oil, minerals). We propose an empirical extrapolation of our findings to assess which domestic factors influence the decision to increase nominal exchange rate stability. Our econometric framework is based on a Markov switching model to allow regime-dependent dynamics of the exchange rate (flexibility versus stability).

The remainder of the paper proceeds as follows. Section 2 presents general anchoring behavior in Sub-Saharan Africa, Section 3 presents the determinants of anchoring to both nominal and real exchange rates. Section 4 proceeds with the empirical application. Section 5 concludes.

\section{Preliminary assessment}

\subsection{Policy mix: some evidence}

A country's exchange rate policy can be defined according to the nature of its peg. Two extreme cases are those in which a country fully fixes either the nominal or the real exchange rate. The in-between cases are defined as a policy mix in which a country combines both objectives by weighting the real and nominal pegs, reflecting a trade-off between decreasing the cost of external debt and enhancing external trade competition (see, for instance, Gervais et al. , 2016; Staveley-O'Carroll and Staveley-O'Carroll , 2017).

The fully nominal peg applies when authorities want to maintain nominal stability of the currency. This objective can be reached by fixing the nominal exchange rate against a single currency or a currency basket. The third option is to control exchange rate variation explicitly or implicitly within a specific margin. The monetary authority chooses to stabilize the variation of reserves in order to stabilize or decrease the cost of external debt.

The fully real peg applies when authorities target variations in the real effective exchange rate (REER). This can be done through a free floating nominal exchange rate or through a managed float. By choosing a real peg, policymakers seek to increase external competition or fight inflation.

Figure 1 describes these two choices by plotting couples of changes in the REER and foreign reserves for SSA countries over the period 2000-2015 (on a monthly average basis). ${ }^{3}$

The $x$ axis displays changes in foreign reserves, while the $y$ axis describes changes in the real exchange rate. Any point located on the latter means that the policymaker has adopted a pure real peg (since there are no foreign exchange interventions). The exchange rate is defined in such a way that a positive change in the real exchange rate reflects real depreciation, and vice-versa for real appreciation. Any point on the $x$ axis illustrates a pure nominal peg policy, since the central bank uses foreign reserves to stabilize the nominal exchange rate.

\footnotetext{
${ }^{3}$ The country sample includes the following countries: Madagascar, Mauritius, Kenya, Uganda, Zambia, Tanzania, Sierra Leone, Guinea-Bissau, Central African Rep., Chad, Rep. of Congo, Gabon, Cabo Verde, São Tomé and Eritrea, Angola, Liberia, Rwanda, Ethiopia, Burundi, Nigeria, Guinea, Senegal, Ghana, Malawi, Mozambique, South Africa, Seychelles, Benin, Burkina Faso, Ivory Cost, Niger, Togo, Cameroon, Comoros, Lesotho, Namibia and Swaziland, Botswana and Gambia. Mali, Sudan, Zimbabwe and Equatorial Guinea are excluded due to missing data.
} 
A policy mix of real and nominal pegs is illustrated by any point located in one of the four areas labeled I, II, III and IV (including the area delineated by the dotted lines). The results are displayed in Table 1.

In area I, the policymaker favors an objective of external competitiveness over foreign debt cost reduction. Indeed, it seeks to depreciate the real exchange rate through nominal depreciation (by buying foreign currency). In area II, the policymakers faces a trade-off between external competitiveness and the cost of external debt. By allowing nominal exchange rate appreciation, it allows for the reduction of debt service cost. Appreciation of the nominal exchange rate leads to depreciation of the real exchange rate if the income effect of the changes in relative prices on income outweighs the substitution effect. In area III, the reduction of the cost of foreign debt is preferred and achieved through nominal appreciation of the currency, although this reduces competitiveness. Area IV illustrates both an increase in the cost of debt (due to nominal depreciation of the domestic currency, as reflected by an increase in foreign exchange reserves) and a loss of competitiveness as a consequence of real appreciation of the domestic currency.

Finally, the dotted lines delineate small variations in the real exchange rate (within a margin of \pm 1 percent) and illustrate situations where a nominal peg was preferred by policymakers (through foreign exchange interventions). This strategy seems to characterize more than half of the country sample, including the WAEMU and CEMAC countries, as well as Botswana, Gambia, Malawi, Mauritius, Mozambique, Namibia, Swaziland, Tanzania and Uganda. Moreover, many of these countries are in area I and area IV, suggesting that their exchange rate regimes are very costly in terms of foreign debt cost and represent significant burdens in terms of their external stability.

As a whole, Figure 1 shows that nominal pegs have detrimental effects on the external competitiveness and debt of many SSA countries (area IV), whereas others have adopted policy mixes with higher weights assigned to real exchange rate targeting and, thus, trade competitiveness (area I). When countries favor real depreciation through nominal depreciation of the domestic currency, they must then bear the costs of this strategy in terms of higher foreign debt servicing due to higher inflation and higher disbursements in the domestic currency. 
Figure 1: Nominal and Real Pegs in Sub-Saharan Africa

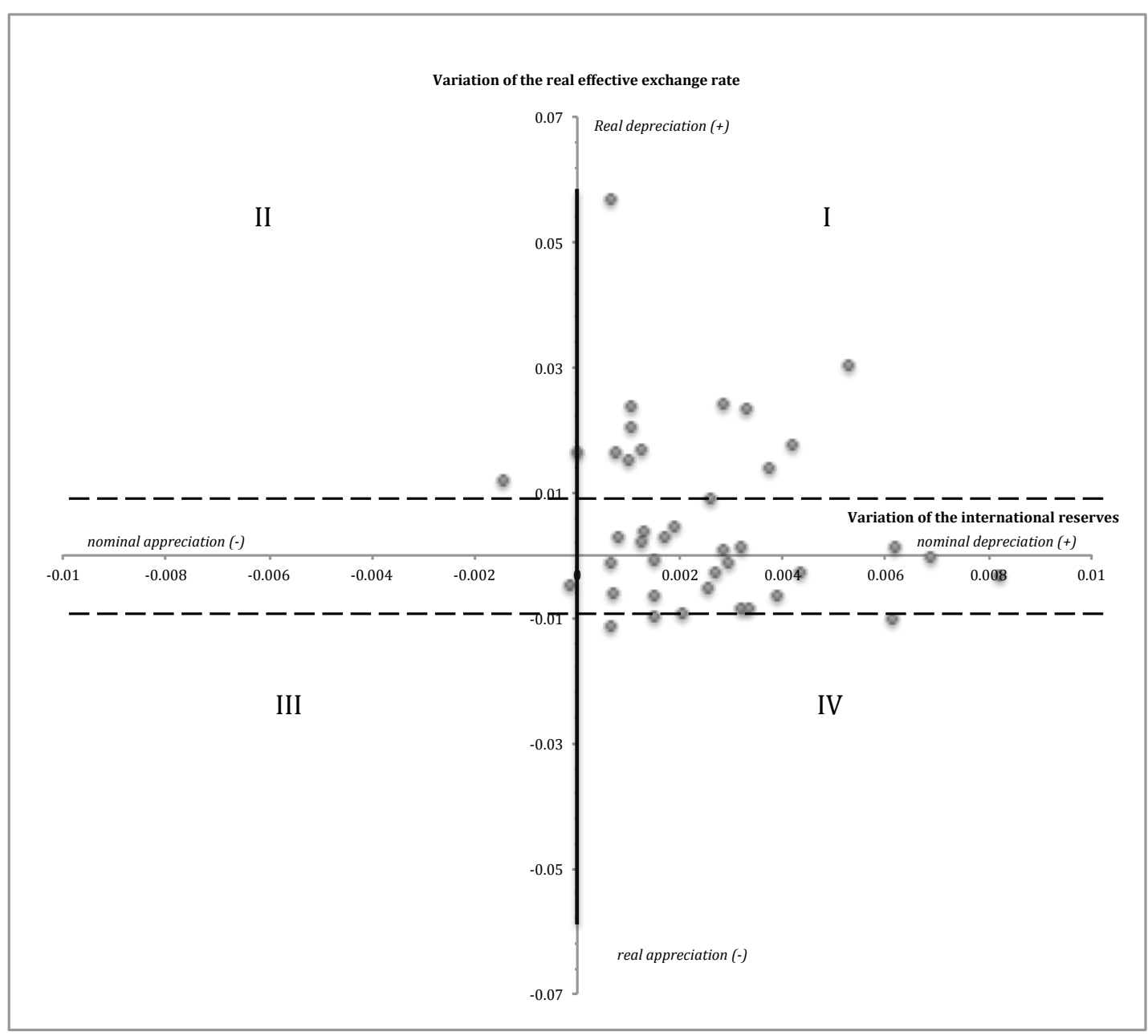


Table 1: Policy mix and de facto exchange rate arrangements in SSA (IMF , 2016a)

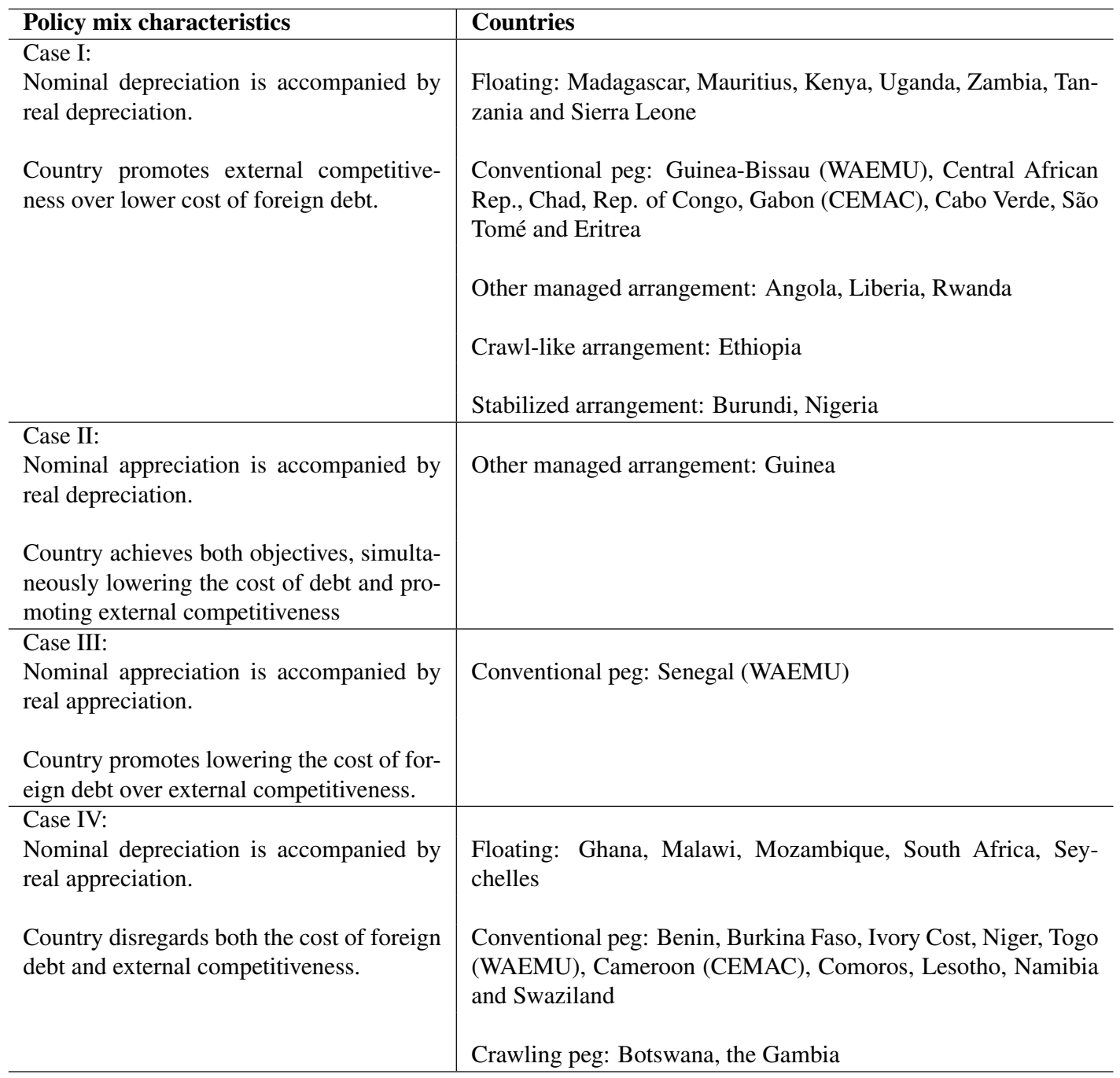

\subsection{Exchange rate policy in SSA: a simple empirical model}

In this sub-section, we propose a simple approach to assessing African exchange rate policy over the period 2000-2017. Our aim is to illustrate the trade-offs that many African countries are facing. That is, they must tighten their nominal pegs given transaction costs (especially foreign debt transactions) associated with greater exchange rate volatility or loosen their peg in the face of balance of payments and trade competitiveness issues. Here, we are interested in estimating the way African countries peg their currencies, which can provide important insight into the mixed peg strategy. As described in the previous sections, for a typical small open economy, a managed float (or any other managed arrangement) might be interpreted as the desire of policymakers to reduce downward pressure on their currency. In this view, the nominal exchange rate is considered a tool with which to control the real exchange rate and, therefore, trade competitiveness. As explained above, this strategy should imply an increase in foreign debt cost.

The evidence regarding a de facto mixed peg policy (real and nominal) can be illustrated using an econometric approach allowing diversity in exchange rate regimes: pure floating, pegged to a basket of currencies and managed float. 
Our empirical investigation is based on an extended version of the following Frankel-Wei model:

$$
\Delta e_{t}=\alpha+\beta_{1} \Delta e_{t}^{U S D}+\beta_{2} \Delta e_{t}^{E U R}+\beta_{3} \Delta e_{t}^{G B P}+\beta_{4} \Delta e_{t}^{Y E N}+\varepsilon_{t}
$$

where $\Delta e$ is the first difference of the natural logarithm of the respective exchange rates (US dollar, euro, British pound, yen and the dependent currency) against an independent numeraire (i.e., the Swiss franc). Estimates of $\beta$ reflect the respective weight of the right-hand side currencies in the implicit basket peg of the left-hand side currency. For instance, a $\beta_{1}$ coefficient close to one implies that fluctuations in the exchange rate are mainly explained by movements in the USD. In this case, the USD can be qualified as the main anchor currency. Obviously, many peg configurations are possible, depending on the exchange rate policy of each country.

We propose a structural version of the Frankel and Wei (1994) model to estimate the degree of nominal exchange rate flexibility as well as the weights on the USD, EUR GBP and CNY in the implicit basket peg of each African country. ${ }^{4}$ To assess the relative importance of shocks from the USD, EUR, GBP and CNY, we estimate the following VAR model for each African currency:

$$
Y_{t}=\mu_{0}+\sum_{k=1}^{P} \Phi_{k} Y_{t-k}+\varepsilon_{t}
$$

where $Y_{t}$ represents the vector of variables $\left(\Delta e^{U S D}, \Delta e^{E U R}, \Delta e^{G B P} ? \Delta e^{C N Y}, \Delta e^{A F C}\right), \Phi_{k}$ is a $5 \times 5$ matrix, and $\mu_{0}$ is a vector of constants. 5 Specifically, we simulate shocks to the USD, EUR, GBP, CNY and the domestic currency to determine the respective weights of their innovations in the fluctuation of each African currency. ${ }^{6}$ The share of home currency shocks is then interpreted as the degree of flexibility because it represents demand shocks to the currency that the authorities allow to be partially reflected in the exchange rate (Frankel and Wei , 2007). Consequently, the higher this share, the lower the share of major currencies, suggesting that the home currency fluctuates more freely.

The dataset obtained from the IMF IFS database covers monthly nominal exchange rates over the period from January 2000 to October 2017 for a sample of 23 African countries: Angola, Botswana, Burundi, Eritrea, Ethiopia, The Gambia, Ghana, Guinea, Kenya, Liberia, Madagascar, Malawi, Mauritius, Mozambique, Nigeria, Rwanda, São Tomé, Seychelles, Sierra Leone, South Africa, Uganda, and Zambia. ${ }^{7}$ Our sample was constrained by data availability, but we took care to reflect the various characteristics of exchange rate policies within the region (see Table 1). ${ }^{8}$ The estimations are carried out for the following sub-samples: 2000:01-2008:09 (sub-sample 1) and 2010:01-2017:10 (sub-sample 2) to reduce the

\footnotetext{
${ }^{4}$ We include the CNY given China's increasing share of total African trade and financial transactions.

${ }^{5}$ This causal ordering reflects their level of exogeneity, with the assumption that the USD is exogenous to contemporaneous shocks on the CNY. This allows us to avoid simultaneity bias since the CNY and African currencies can be simultaneously affected by the USD. Note that alternative causal orderings have been used, with $\Delta e^{E U R}$ exogenous to $\Delta e^{U S D}$. These estimation results, which are not presented here but are available upon request, do not lead to different conclusions.

${ }^{6}$ These innovations are orthogonalized using the Cholesky decomposition, while the weight computations are done through VAR-based variance decomposition of forecast errors.

${ }^{7}$ We use monthly data because higher frequency data are not available for all countries over the study period. Moreover, we use the Swiss franc $(\mathrm{CHF})$ as an independent numeraire to measure exchange rate movements. Special Drawing Rights (SDR) and the Australian dollar have been also considered but no significant changes in the results have been observed.

${ }^{8}$ To avoid collinearity issues with the euro, we exclude from the sample the African Countries belonging to the following African monetary unions: the West African Economic and Monetary Union (WAEMU), the Economic and Monetary Community of Central Africa (EMCCA) and the Common Monetary Area (CMA). For, Namibia, Lesotho and Swaziland (CMA), which are pegged to the South African rand, the results are logically identical to those of South Africa.
} 
effects of the 2008-2009 financial crisis.

Table 2 displays the variance decomposition for each African currency over the two sub-periods. For each sub-sample, each column gives the percentage of forecast error variance due to currency innovations. Accordingly, each row adds up to 100 . The first four columns show the de facto implicit basket weights and the degree of exchange rate flexibility of each African currency before the 2008-2009 financial crisis. Angola, for instance, is mainly driven by country-specific shocks, which account for more than $57 \%$ of Angola's exchange rate variations. USD shocks explain more than $26 \%$ of Angola's exchange rate variations, while the euro, pound sterling and yuan have a limited impact (less than 10\%). We can conclude that Angola's monetary authority manages, to some extent, the nominal exchange rate against the USD, although it allows a high degree of flexibility.

As a whole, the GBP and CNY shares are both negligible, amounting to less than $9 \%$ in all African countries. The euro share is also quite low, except in Cabo Verde (43\%), which has adopted a soft peg to a currency basket composed mainly of the euro and the USD. Furthermore, we find that the USD accounts for an important percentage of African currency variations. Indeed, the role of the USD was particularly high (more than 40\%) during the 2000s in Eritrea, Ethiopia, Ghana, Kenya, Mauritius, Nigeria, Rwanda, São Tomé, Sierra Leone and Uganda.

In the second sub-sample, we note that the USD plays an increasing role in many countries. For instance, the USD weight has more than doubled in seven countries (Angola, Botswana, Burundi, Guinea, Liberia, Madagascar and Sierra Leone), while for 10 countries, the weight has increased by at least $37 \%$. The USD weight is now higher than $50 \%$ for 12 countries compared to 8 countries in the first sub-sample. Conversely, the USD weight has decreased significantly for only four countries (Ethiopia, Malawi, Nigeria, São Tomé). These higher USD shares have resulted in smaller shares of countryspecific shocks, although the degree of exchange rate flexibility remains significant (higher than $40 \%$ ) for 10 countries and higher than $70 \%$ for 3 countries (Gambia, Zambia and Malawi). The euro displays a share higher than 50\% for Cabo Verde and Mauritius. As a whole, the CNY, GBP and EUR shares remain weak.

This evidence is in line with the fear of floating phenomenon. As African countries move towards floating exchange rate regimes, they are strongly affected by commodity shocks. Accordingly, they tend to avoid currency appreciation by pegging their currencies to the commodity currency, i.e., the USD (Chan and Rogoff , 2003). Furthermore, African countries tend to favor managed arrangements to minimize transaction costs associated with greater exchange rate flexibility, such debt securities transactions. As transaction costs increase with exchange rate volatility, it is optimal for countries to tighten their pegs on the USD. However, they tend to preserve a degree of exchange rate stability in order to address balance of payments issues and depreciation pressure and, thus, avoid real exchange rate misalignment (see, Gnimassoun , 2015). This duality in exchange rate behavior clearly shows that African countries face a trade-off between foreign debt costs and trade competitiveness. In the next section, we propose a theoretical framework that explains how African countries can cope with these conflicting objectives. 
Table 2: Variance decomposition of forecast errors as a $\%$ of the total variance of African exchange rates.

\begin{tabular}{|c|c|c|c|c|c|c|c|c|c|c|}
\hline \multirow[b]{2}{*}{ Innovations } & \multicolumn{5}{|c|}{ 2000:01-2008:09 } & \multicolumn{5}{|c|}{ 2010:01-2017:10 } \\
\hline & $\varepsilon_{U S D}$ & $\varepsilon_{E U R}$ & $\varepsilon_{G B P}$ & $\varepsilon_{C N Y}$ & $\varepsilon_{A F C}$ & $\varepsilon_{U S D}$ & $\varepsilon_{E U R}$ & $\varepsilon_{G B P}$ & $\varepsilon_{C N Y}$ & $\varepsilon_{A F C}$ \\
\hline Angola & 26,23 & 8,84 & 2,15 & 5,23 & 57,56 & 55,70 & 0,01 & 1,28 & 8,14 & 34,87 \\
\hline Botswana & 15,05 & 11,95 & 1,95 & 1,42 & 69,6 & 38,98 & 0,51 & 0,47 & 3,19 & 56,83 \\
\hline Burundi & 33,53 & 1,01 & 1,49 & 0,08 & 63,90 & 87,82 & 0,17 & 0,15 & 1,64 & 10,21 \\
\hline Cabo Verde & 19,58 & 43,74 & 0,84 & 1,58 & 34,26 & 25,96 & 57,42 & 0,94 & 0,47 & 15,21 \\
\hline Eritrea & 51,29 & 2,66 & 1,77 & 2,79 & 41,48 & 95,62 & 0,21 & 0,87 & 2,51 & 0,79 \\
\hline Ethiopia & 80,80 & 7,68 & 8,69 & 1,17 & 1,67 & 65,44 & 0,75 & 1,03 & 0,47 & 32,31 \\
\hline The Gambia & 25,23 & 4,47 & 0,83 & 5,09 & 64,39 & 22,05 & 1,82 & 0,68 & 4,50 & 70,95 \\
\hline Ghana & 47,00 & 7,18 & 5,75 & 5,09 & 34,98 & 39,01 & 1,24 & 1,06 & 3,59 & 55,11 \\
\hline Guinea & 15,35 & 7,38 & 3,15 & 0,23 & 73,88 & 71,51 & 0,31 & 1,76 & 6,21 & 20,21 \\
\hline Kenya & 50,51 & 7,50 & 3,25 & 2,22 & 36,52 & 60,55 & 0,67 & 0,20 & 1,39 & 37,20 \\
\hline Liberia & 20,26 & 1,06 & 0,27 & 3,26 & 75,15 & 75,19 & 0,14 & 0,42 & 1,59 & 22,65 \\
\hline Madagascar & 8,55 & 10,28 & 5,09 & 1,35 & 74,73 & 37,74 & 5,71 & 0,60 & 0,24 & 55,70 \\
\hline Malawi & 34,52 & 2,82 & 7,42 & 2,07 & 53,17 & 6,22 & 0,25 & 1,45 & 4,37 & 87,71 \\
\hline Mauritius & 52,85 & 3,09 & 2,86 & 2,93 & 38,27 & 54,28 & 24,29 & 0,38 & 0,34 & 20,71 \\
\hline Mozambique & 31,01 & 2,59 & 4,95 & 1,22 & 60,23 & 27,12 & 0,99 & 1,85 & 0,26 & 69,78 \\
\hline Nigeria & 74,71 & 1,23 & 4,60 & 3,89 & 15,57 & 22,88 & 1,50 & 5,26 & 4,82 & 65,54 \\
\hline Rwanda & 81,18 & 0,82 & 3,54 & 3,65 & 10,81 & 94,43 & 0,02 & 0,74 & 1,81 & 3,00 \\
\hline São Tomé & 77,50 & 1,05 & 3,17 & 1,68 & 16,59 & 26,07 & 71,76 & 0,61 & 0,07 & 1,49 \\
\hline Seychelles & 37,67 & 0,35 & 4,60 & 1,16 & 56,23 & 60,97 & 0,39 & 0,18 & 1,22 & 37,24 \\
\hline Sierra Leone & 41,00 & 3,03 & 6,47 & 2,48 & 47,02 & 77,59 & 1,17 & 1,60 & 7,06 & 12,58 \\
\hline South Africa & 13,35 & 12,10 & 0,21 & 0,35 & 73,99 & 17,19 & 0,85 & 4,09 & 2,55 & 75,33 \\
\hline Uganda & 57,08 & 1,35 & 1,96 & 2,73 & 36,88 & 52,08 & 2,45 & 1,36 & 3,46 & 40,65 \\
\hline Zambia & 21,57 & 2,96 & 2,99 & 4,71 & 67,77 & 14,29 & 3,40 & 1,68 & 9,42 & 71,22 \\
\hline
\end{tabular}

Notes: The optimal lag lengths were selected according to the Akaike criterion. The lag length ranges are 1 and 3 , depending the country and the sample period. 


\section{Theoretical model}

\subsection{General features}

To represent these African economies, we consider a small open economy (the domestic country) vis-à-vis the rest of the world. The latter is divided into two areas: a euro zone and a dollar zone. The domestic country may choose to peg its currency to the euro and the US dollar. Although we limit the basket peg to two currencies for simplicity, our arguments are valid for a higher number of currencies in the basket.?? The central bank chooses from among a variety of exchange rate regimes. In the case of an intermediate regime, we consider a soft peg in the sense that the policymaker allows the exchange rate to fluctuate around a central parity within a given band. Our goal is to examine the main motivations that drive an African country to adopt such an intermediate regime rather than a corner solution (pure float or hard peg). An essential feature of the model is that the domestic country issues debt denominated in foreign currencies and therefore accumulates foreign liabilities. The central bank decides the optimal weights on the euro and the US dollar in the basket and chooses the degree of flexibility of the exchange rate. It does so while seeking to minimize the variance of the internal real exchange rate and international reserves.

The model is built upon several assumptions that characterize the situations of developing or emerging African countries: i) Their foreign debt is high and a pure float regime may overweight the debt burden if the domestic currency depreciates. For this reason, limiting exchange rate fluctuations may be advantageous. ii) In many articles, the optimal design of basket-peg arrangements relies on the UIP assumption to relate the domestic interest rate to foreign interest rates. This assumption, however, is at odds with empirically low African capital market integration with international financial markets. One reason for deviation from UIP is the existence of additional lending costs due to the scarcity of funds in these domestic financial markets. We use this assumption in our model. iii) In addition to debt problems, we examine the role of the real exchange rate as a factor in external imbalances when people consume both locally produced (non-tradable) goods and imported goods (tradable) that are imperfect substitutes.

We consider an economy populated with households that are identical and own firms. They consume locally produced goods (non-tradable goods and services) and tradable goods imported from abroad. In the domestic country, there are three categories of firms: i) firms in the export sector sell commodity goods abroad whose prices and quantities sold are exogenous and fixed by the rest of the world; ii) firms in the tradable imported good sector import commodity goods and sell them in the domestic market; and iii) finally, in the non-tradable goods sector, firms hire workers to produce domestic goods and supply domestic services. In addition to the real sector, the model includes financial markets and a monetary sector. Demand for money is introduced through a cash-in-advance constraint. Moreover, we assume that the exchange rate between the domestic currency and the foreign countries is not given by the UIP condition (which amounts to assuming that there is not perfect capital mobility between the domestic country and its foreign partners). The central parity of the domestic currency is described by a peg to a two-currency basket and since it is a small country, foreign interest rates are exogenous. Net borrowing is assumed to be positive, so that consumers hold neither foreign assets nor domestic assets. They issue domestic assets that are held by foreign countries. 


\subsection{The model}

\subsubsection{The households}

We consider a cash and credit economy. The representative household gains utility from the consumption of a nontradable good $C_{N t}$ and a tradable (imported) good $C_{T t} \cdot{ }^{9}$ The consumer-worker obtains disutility from working $\left(l_{t}\right.$ is the labor supply) and maximizes the present discounted value of utility: ${ }^{10}$

$$
\max E_{0}\left[\Sigma_{\tau=0}^{\infty} \beta^{t+\tau} U\left(C_{N t+\tau}, C_{T t+\tau}, l_{t+\tau}\right)\right]
$$

$$
U\left(C_{N t}, C_{T t}, l_{t}\right)=(1-\alpha) \ln C_{N t}+\alpha \ln C_{T t}-\gamma l_{t},
$$

where $\beta=(1+\rho)^{-1}$ is the discount factor, $\rho$ is the time preference rate, and we assume that $0<\alpha<1$ and $\gamma>0$. The non-tradable good is purchased using cash $m_{t}$. The tradable good is purchased on credit. The households hold two assets: money and IOU bonds. They borrow money from abroad for a one-period maturity and in turn hold a bond indicating the amount of debt owed. At time $t$, the amount owed in foreign currency is $-B_{t+1}$ (with $B_{t+1}>0$ ). We use the index $t+1$ to indicate that this is the amount borrowed at time $t$ to be reimbursed at time $t+1$. The equivalent amount in terms of the domestic currency is calculated by taking into account the "composite" nominal exchange rate prevailing at the time of reimbursement $-\bar{e}_{t+1}^{a} B_{t+1} \cdot \bar{e}_{t}$ is the price of the domestic composite exchange in terms of the foreign currencies to be defined below (an increase in $\bar{e}_{t}$ means depreciation of the domestic currency). $\bar{e}_{t+1}^{a}$ is the expectation at time $t$ of the nominal exchange rate that will prevail at time $t+1$. The term "composite" is used because there are multiple foreign lenders (here, the US and European countries) and the domestic country may adopt a basket peg regime. Finally, we assume that the IOU asset costs $r_{t}$, the interest rate paid on foreign debt between time $t-1$ and time $t$. The household faces cash-in-advance and budget constraints for $t=1, \ldots, \infty$ :

$$
P_{N t} C_{N t} \leq m_{t}-\left(1+r_{t}\right) \bar{e}_{t} B_{t}+\bar{e}_{t+1}^{a} B_{t+1},
$$

$$
P_{N t} C_{N t}+P_{T t} C_{T t}-\bar{e}_{t+1}^{a} B_{t+1}+m_{t+1} \leq w_{t} l_{t}+\left[m_{t}-\bar{e}_{t} B_{t}\left(1+r_{t}\right)\right]+\Pi_{t}+\Omega_{t}
$$

where $\Omega_{t}=P_{x t} X_{t}, \Pi_{t}=\left(\operatorname{prof}_{N t}+\operatorname{prof}_{T t}\right) . P_{N t}$ is the unit price of the non-tradable good at time t. $P_{T t}$ is the unit price of the tradable good. We assume that the households own the firms. $w_{t}$ is the wage rate. The household's income has several components: labor income $w_{t} l_{t}$, domestic profits $\Pi_{t}$, and export revenues $\Omega_{t}$. prof $f_{N t}$ and $\operatorname{prof}_{T t}$ (defined below)

\footnotetext{
${ }^{9}$ In what follows, we shall use the terms "non-tradable" and "non-traded" for locally produced goods and "tradable" or "non-traded" for imported goods.

${ }^{10}$ In the model, consumption includes both private and public consumption, which means that we do not distinguish the government from the households. An agent's debt is therefore equivalent to the domestic country's sovereign debt. We choose a logarithmic function for consumption for convenience.
} 
are the profits from activities in the non-tradable goods sector and the tradable goods sector, respectively. $P_{X t} X_{t}$ is the value of commodity exports invoiced in the domestic currency. $P_{X t}$ is the unit export price, and $X_{t}$ is the volume of exports. Exports refers here to a commodity good extracted from the soil and directly sold abroad (e.g., primary goods, oil, minerals). The household optimization problem is to choose a sequence $C_{T t}, C_{N_{t}}, m_{t}, l_{t}$ and $B_{t}$ to maximize Eq. (3a) subject to constraints (4) and (5), taking the composite exchange rate $\bar{e}_{t}$, prices $P_{X t}, P_{T t}, P_{N t}, w_{t}$, profits prof $f_{N t}$ and prof $f_{T t}$, volume of exports $X_{t}$, initial stock of debt $B_{0}$ and cash $m_{0}$ as given. We define $\varphi_{t}=\left(\left(P_{N t}\right) /\left(P_{T t}\right)\right)$ as the real exchange rate at time t. From standard first-order conditions, we obtain the following relationships. The shares of non-tradable and tradable consumptions of total consumption are given by:

$$
\begin{aligned}
& \left(C_{N t} /\left(C_{N t}+C_{T t}\right)\right)=(1-\alpha) /\left((1-\alpha)+\alpha \varphi_{t}\left(1+r_{t}\right)\right), \\
& \left(C_{T t} /\left(C_{N t}+C_{T t}\right)\right)=\left(\alpha\left(1+r_{t}\right) \varphi_{t}\right) /\left((1-\alpha)+\alpha \varphi_{t}\left(1+r_{t}\right)\right) .
\end{aligned}
$$

A higher interest rate makes the current tradable good less expensive relative to the non-traded good (because debt becomes more costly) and, thus, increases the current consumption of this good (a substitution effect). At the same time, the increase in the interest rate reduces the consumer's total income, which leads to less consumption of both goods (an income effect). Because there is a distinction in the model between cash and credit goods, any change in a given price has an impact on the credit good through both substitution and income effects, while the impact on the cash good comes only from income effects. As a consequence, the non-tradable good share of total consumption diminishes. Similarly, an increase in the real exchange rate reduces the non-tradable good share of total consumption. Here, $P_{t} Y t=P_{T t} C_{T t}+P_{N t} C_{N t}$ denotes total consumption spending on cash and credit goods, and noting that the only money held will finance cash goods $\left(m_{t}=P_{N t} C_{N t}\right)$, the velocity of money is

$$
v_{t}=P_{t} Y_{t} / m_{t}=1+\left(1 / \rho_{t}\right)\left(C_{T t} / C_{N t}\right)=1+(\alpha /(1-\alpha))\left(1+r_{t}\right) .
$$

Eq. (7) implies that real money demand varies negatively with the interest rate (for instance, a decrease makes holding the IOU asset or, equivalently, selling domestic assets abroad more attractive than holding money).

\subsubsection{Firms in the non-tradable goods sector}

We assume that the production function in the competitive non-tradable goods sector is linear in labor demand:

$$
Y_{N t}=L_{t} .
$$

Capital is fixed (and normalized to 1), and a similar assumption applies to productivity. The representative firm maximizes the following profit with respect to $Y_{N t}\left(L_{t}\right.$ is labor demand):

$$
\operatorname{prof}_{N t}=P_{N t} Y_{N t}-w_{t} L_{t} .
$$


Profit maximization implies

$$
P_{N t}=w_{t}
$$

At the competitive equilibrium, profits equal zero.

\subsubsection{Firms in the tradable goods sector}

The tradable goods sector consists of two representative firms. Firm 1 produces and exports commodity goods at a price that is set by international markets $P_{X t}$. The volume of exports $X_{t}$ is also determined by foreign demand and is exogenous. We assume that export activities are performed by self-employed people who are paid the income from their exports $P_{X t} X_{t}$. Firm 2 imports goods and sells them in the domestic markets. People in these firms are also self-employed. Self-employment activities are common in the tradable goods sector in Africa, since small firms in this sector belong to diaspora communities (e.g., Lebanese, Indian or, more recently, Chinese merchants). The import sector is described by a representative monopolistic firm. The latter sells a good imported from outside in the domestic market. Profits are:

$$
\begin{aligned}
\operatorname{prof}_{T t} & =\left(P_{T t}-\bar{e}_{t} P_{M t}\right) Y_{T t}, \\
Y_{T t} & =C_{T t} .
\end{aligned}
$$

The firm in the import sector faces a demand for traded goods and sets its price $P_{T t} . P_{M t}$ is the price of imports denominated in foreign currencies. Exchange rate pass-through is the way in which the nominal exchange rate affects import prices and the prices of tradable goods depends upon the exchange rate regime. In a hard peg regime $\left(\bar{e}_{t}\right.$ is fixed), there is full pass-through. In a floating exchange rate (partial or free float) regime, nominal exchange rate fluctuations can dampen the effects of changes in import prices. The monopoly chooses to maximize Eq. (11) subject to the demand function for traded goods, resulting in an optimal price:

$$
\begin{aligned}
P_{T t} & =\left(1+\mu_{t}\right) \bar{e}_{t} P_{M t}, \\
\mu_{t} & =1 /\left(\left|\epsilon_{t}\right|-1\right), \\
\epsilon_{t} & =\left(P_{T t}\left(\partial C_{T t}\right) /\left(\partial P_{T t}\right)\right) / C_{T t}=-(\alpha / \gamma) \varphi_{t} Y_{N t}, \\
\epsilon_{t} & <-1 .
\end{aligned}
$$

We assume that $\epsilon_{t}<-1$, since traded and non-traded goods are imperfect substitutes.

\subsubsection{Exchange rate regimes}

SSA countries may use some forms of intermediate exchange rate regimes (soft pegs or managed floats), because their capital accounts are still not completely open to international capital flows. They borrow money in international capital markets, but their own domestic financial markets are still shallow and illiquid. An intermediate regime (between the corner solutions of a hard peg or a free float) can be a first step towards deeper financial integration with the rest of the world through a mechanism similar to the former European Exchange Rate Mechanism (ERM) (fixed exchange rate 
currency margins or a semi-pegged regime). Exchange rate movements depend upon the current account. The balance of payments and foreign reserves are the sum of trade balance, debt service and foreign liabilities (positive official transfers):

$$
-r_{t} \bar{e}_{t} B_{t}+\bar{e}_{t+1}^{a} B_{t+1}=-\Delta R E S_{t}
$$

where $\triangle R E S_{t}$ denotes changes in net international reserves at time $t$. Moreover, the rate of nominal exchange rate adjustment is limited by the central bank's interventions in the exchange rate market. The resulting changes in foreign reserves are as follows:

$$
\Delta R E S_{t}=-\theta_{1} \widetilde{\lambda}_{t}+\Delta L_{t}+\Delta U_{t}, \widetilde{\lambda}_{t}=\bar{e}_{t}-e_{t}^{c}
$$

A semi-pegged regime can be modeled as a target zone with central bank interventions. We define $e_{t}^{c}=\lambda_{1} e_{t}^{u s}+\lambda_{2} e_{t}^{\text {euro }}$ as the (log) central parity. $e_{t}^{u s}$ and $e_{t}^{\text {euro }}$ are the bilateral nominal exchange rate of the domestic currency against the US Dollar and the Euro, respectively (where an increase indicates a depreciation of the domestic currency). $\lambda_{1}$ and $\lambda_{2}$ are their weights in the basket $\left(\lambda_{1}+\lambda_{2}=1\right)$. In a semi-pegged regime, we assume that the money supply is bounded between $M_{t}^{\min }$ and $M_{t}^{\max }$. Here, $M_{t}^{\min }$ is reached when $\bar{e}_{t}=\bar{e}^{\min }$, and $M_{t}^{\max }$ is reached when $\bar{e}_{t}=\bar{e}^{\max } . \bar{e}^{\min }$ and $\bar{e}^{\max }$ are the lowest and highest values, respectively, of the composite nominal exchange rate. The respective amount of intervention at each boundary is indicated by $\Delta L$ and $\Delta U$. Eq. (14) is useful for studying policymakers' choices in several situations.

- $\theta_{1}=0$ and $\Delta L_{t}=\Delta U_{t}=0$. This case corresponds to a free floating regime. The central bank does not intervene in exchange rate market to stabilize the nominal exchange rate. In this case, $\widetilde{\lambda}_{t} \rightarrow \pm \infty$ (the exchange rate is allowed to deviate from the central parity with no limit).

- $\theta_{1}=0$ and $\Delta L_{t} \neq 0, \Delta U_{t} \neq 0$. This case corresponds to a managed float regime. Foreign reserves are used to monitor exchange rate movements within a band $\left[\bar{e}^{\min }, \bar{e}^{\max }\right]$. The central bank sets upper and lower limits to the exchange rate changes by defining a target band. This target remains unchanged $\left(\theta_{1}=0\right.$ means that there are no intra-band interventions; therefore, $\left.\Delta L_{t}=\Delta L<\infty, \Delta U_{t}=\Delta U<\infty\right)$.

- $\theta_{1} \rightarrow \infty$ and $\Delta L_{t} \rightarrow \infty, \Delta U_{t} \rightarrow \infty$. This case describes a hard peg, a regime characterized by unlimited central bank interventions to maintain the fixed exchange rate (in this case, $\widetilde{\lambda}_{t}=0$ ).

- $0<\theta_{1}<\infty$ (crawling band). This case is similar to the managed float regime, but this time, $\Delta L_{t}$ and $\Delta U_{t}$ are time varying and remain bounded.

\subsubsection{Interest rates}

We now present our assumptions about the determination of the domestic interest rate $r_{t}$. Since they are constrained in their domestic markets and must borrow money from abroad, households have to incur an additional cost to service their debt. This additional cost represents an amount they have to pay to foreign lenders for making foreign funds available. This additional cost represents an interest rate margin for the lenders over the interest rate that would correspond to UIP. 
Using $\xi$ as the interest rate differential, we write

$$
\begin{aligned}
& \xi_{t}^{u s}=\left(r_{t}-r_{t}^{u s}\right)-\left(E_{t} e_{t+1}^{u s}-e_{t}^{u s}\right), \xi_{t}^{u s}>0, \\
& \xi_{t}^{\text {euro }}=\left(r_{t}-r_{t}^{\text {euro }}\right)-\left(E_{t} e_{t+1}^{\text {euro }}-e_{t}^{\text {euro }}\right), \xi_{t}^{\text {euro }}>0,
\end{aligned}
$$

where $\xi_{t}^{u s}$ and $\xi_{t}^{\text {euro }}$ would equal zero under the UIP assumption, which is not our assumption. One could also imagine that funds borrowed from abroad are not given directly to the households but to a bank (a subsidiary of an international financial company could borrow the funds at an interest rate corresponding to that of the UIP and lend them at a higher interest rate). In that case, UIP would not be satisfied because domestic financial markets are thin, illiquid, and shallow, so the domestic interest is higher than foreign interest rates in international capital markets. The rate is so high that even with appreciation of the foreign currency, the expected rate of appreciation would not be enough to offset the savings accrued from the positive interest rate differential. $E_{t} e_{t+1}^{u s}$ and $E_{t} e_{t+1}^{\text {euro }}$ are the expectations at time $t$ of the domestic exchange rate relative to the US dollar and the euro, respectively, at time $t+1$. Assuming perfect capital mobility between the US and the euro area implies that

$$
\xi_{t}^{u s}=\xi_{t}^{\text {euro }}=\xi_{t}
$$

This means that there is no borrowing-cost arbitrage by borrowers between the US and European financial markets. Otherwise, at a given period $t$, the households would choose to issue foreign debt in the country with the lowest $\xi_{t}$. We thus write

$$
r_{t}=r_{t}^{u s}+\left(E_{t} e_{t+1}^{u s}-e_{t}^{u s}\right)+\xi_{t}=r_{t}^{\text {euro }}+\left(E_{t} e_{t+1}^{\text {euro }}-e_{t}^{\text {euro }}\right)+\xi_{t},
$$

where $\xi_{t}$ can be thought of as either a finance premium that compensates the foreign lender for bearing verification costs due to informational asymmetries or as a premium due to the possibility of default on the debt.

\subsection{Ranking the exchange rate regimes}

\subsubsection{The choice of the exchange rate regime}

Policymakers are concerned about stabilizing fluctuations in the real exchange rate and in foreign reserves. We solve the model and obtain the following expressions for the real exchange rate and foreign reserves (see the details in Appendix (A)):

$$
\varphi_{t}=D_{t}\left(\frac{1}{\overline{e_{t}}}\right)=\frac{D_{t}\left[\theta_{1}-\overline{C_{t}}\right]}{A_{t}+\theta_{1}\left[\lambda_{1} e_{t}^{u s}+\left(1-\lambda_{1}\right) e_{t}^{\text {euro }}\right]},
$$


and

$$
\Delta R E S_{t}=\frac{\theta_{1}\left[A_{t}+\overline{C_{t}} \lambda_{1} e_{t}^{u s}+\left(1-\lambda_{1}\right) \overline{C_{t}} e_{t}^{\text {euro }}\right]+\overline{X_{t}}\left[\theta_{1}-\overline{C_{t}}\right]}{\left[\theta_{1}-\overline{C_{t}}\right]},
$$

where $A_{t}, D_{t}, \bar{C}_{t}$ and $\bar{X}_{t}$ are defined by:

$$
\begin{aligned}
& A_{t}=\frac{\alpha w_{t} Y_{N t} Y_{T t}}{\delta(1-\alpha)\left(Y_{t}-Y_{N t}\right)}+(1+\delta) P_{X t} X_{t}+(1-\delta \omega) P_{N t} Y_{N t}-m_{t+1}+\overline{X_{t}}, \\
& D_{t}=\frac{w_{t}}{P_{M t}\left\{\frac{(1-\alpha)}{\gamma} \delta\left(Y_{t}-Y_{N t}\right)\right.}, \\
& \overline{C_{t}}=B_{t}-P_{M t} Y_{T t}\left(1-Y_{N t}\right)(1+\delta \omega), \\
& \overline{X_{t}}=\Delta L_{t}+\Delta U_{t}, \\
& \delta=\frac{1}{1+r_{t}}, \omega=\left(1+\frac{1-\alpha}{1+r_{t}}\right) .
\end{aligned}
$$

We now consider the main determinants of $A_{t}, D_{t}, \bar{C}_{t}$ and $\bar{X}_{t}$. They describe the macroeconomic environment that influences the policymaker's optimal choice to be studied in the next sections. The first component of $A_{t}$ can be rewritten as:

$$
\frac{\alpha w_{t} Y_{N t} Y_{T t}}{\frac{(1-\alpha)}{\left(1+r_{t}\right)}\left(Y_{t}-Y_{N} t\right)}=\gamma^{2} \frac{\mu_{t}}{1+\mu_{t}} \bar{e}_{t} P_{M t} Y_{T t}
$$

The key variable is $\frac{\mu_{t}}{1+\mu_{t}}$, a proxy for the degree of pass-through from the import price to the price of tradable goods. If $\mu_{t}=0$, the demand for traded goods is price inelastic, and firms in the traded goods sector can fully pass-through changes in import prices to the prices of the tradable goods. If $\left|\mu_{t}\right| \neq 0$, pass-through is incomplete. The ratio $\frac{\mu_{t}}{1+\mu_{t}}$ can be thought of as a measure of the degree of trade integration with the rest of the world (an indicator of competition in the domestic goods market). Equation (18) shows that a higher $A_{t}$ stemming from this first component is consistent with a lower real exchange rate $\varphi_{t}$. The remainder in Eq. (20a) can be written as follows:

$$
P_{X t} X_{t}+\frac{P_{t} Y_{t}}{1+r_{t}} \text { open }_{t}-\left(\frac{\alpha}{1-\alpha} P_{N t} Y_{N t}\right)\left(\frac{v_{t}}{v_{t}-1}\right)+\left(1+\frac{1-\alpha}{\left(1+r_{t}\right)^{2}}\right) P_{N t} Y_{N t}-m_{t+1}+\overline{X_{t}},
$$


where open $_{t}$ is the degree of trade openness defined as the sum of exports $P_{X t} X_{t}$ and imports $P_{T t} Y_{T t}$ as a share of GDP $P_{t} Y_{t}$. One expects higher openness to be associated with lower prices of non-tradable goods and therefore with a lower real exchange rate. The ratio $v_{t} /\left(v_{t}-1\right)$ is an index of the velocity of money. Insofar as non-traded goods are cash goods, high money demand (high $v_{t}$ ) indicates a preference for these goods relative to traded goods. Conversely, when $v_{t} \rightarrow 0$, low money demand reflects a preference for tradable goods. An increase in $v_{t}$ is associated with a higher real exchange rate $\varphi_{t}$, since higher money demand increase the relative price of non-traded goods. A higher $v_{t}$ means a lower $A_{t}$ and, by Eq. (18), this implies a higher $\varphi_{t}$.

The nominal interest rate represents the cost of debt servicing. An increase implies a decrease in the demand for the credit (tradable) good and therefore a higher real exchange rate. From Eq. (17), we deduce that $r_{t}$ depends upon the nominal foreign interest rates, the financial risk premium and the expected changes in the nominal exchange rate of the domestic currency against the US dollar (or the euro).

As for the other variables, $\overline{C_{t}}$ has a one-to-one relationship with the value of debt denominated in a foreign currency. Higher debt resulting from greater borrowing allows the greater consumption of traded goods (credit goods), thereby implying an increase in the relative price of this good and therefore a decrease in the real exchange rate. $\overline{X_{t}}$ is the band width of the "composite" nominal exchange rate $\overline{e_{t}}$. Narrowing the band for permissible exchange rate fluctuations can prevent excessive nominal exchange rate appreciation and depreciation. We therefore expect any change in $\overline{X_{t}}$ to be negatively correlated with changes in $\overline{e_{t}}$. From Eq. (18), we expect a positive correlation with any change in the real exchange rate. Using Eq. (20b), it can be shown that

$$
D_{t}=\frac{2\left(1+\mu_{t}\right)}{\frac{\alpha}{\gamma} C_{N t}}
$$

$D_{t}$ is therefore a function of the price elasticity of the demand for the traded good. Its impact on the real exchange rate is similar to that of the ratio $\mu_{t} /\left(1+\mu_{t}\right)$ examined above.

\subsubsection{Solving the model for the exchange rate and foreign reserves}

From Eqs. (18) and (19), we obtain

$$
\varphi_{t}=\frac{D_{t}}{\overline{X_{t}}-\Delta R E S_{t}+\theta_{1}\left[\lambda_{1} e_{t}^{u s}+\left(1-\lambda_{1}\right) e_{t}^{e u r o}\right]} .
$$

This expression of the real effective exchange rate ( $\varphi_{t}$ in level) explains the choice of the country's anchor regime according to two important variables: $a=D_{t}$ and $b=\overline{X_{t}}+\theta_{1}\left[\lambda_{1} e_{t}^{u s}+\left(1-\lambda_{1}\right) e_{t}^{\text {euro }}\right]$.

$D_{t}$ is a function of the monopolistic power in the traded goods market and can be considered a proxy for the degree of trade integration with the rest of the world (see Eq. (23)). A positive value of $D_{t}$ indicates a relatively high degree of integration reflected by lower monopolistic power in the traded goods market. Conversely, a low degree of trade integration is captured by a negative value of $D_{t}$.

Regarding $b$, in the denominator, the expression captures the degree of exchange market intervention. Frequent interventions, suggesting a harder peg, are associated with positive values of $b$, while infrequent interventions are associated with negative values. 
Figure 2 shows appreciation or depreciation of the real effective exchange rate with regards to changes in reserves and, thus, the nominal exchange rate. The increase in changes in reserves reflects nominal exchange rate depreciation. The dotted lines show how the curve moves after an increase in $b$. The upper two cases show countries with high integration $(a>0)$. These types of countries and the two lower cases show countries with low integration $(a<0)$.

When countries have low integration with the rest of the world $(a<0)$, the curve shows that an increase in changes in reserves (or slowing of the decrease in changes in reserves) would cause appreciation of the real effective exchange rate. As changes in reserves increase, the curve decreases, reflecting the policy mix anchor. Indeed, in a real anchor policy, the monetary authority would depreciate the rate sufficiently to cause real depreciation. This is reflected in the case where countries have high integration with the rest of the world $(a>0)$. Therefore, the mixed policy case is constrained by the integration degree and the amount of local monopolistic power. The lower world trade integration is and the higher monopolistic power, the higher the probability that a country chooses a policy mix anchor.

Finally, the sign of $b$ does not impact the choice of anchor, but it does impact the degree of the anchor. For a given sign of $a$, the different signs and values of $b$ are reflected by the same curves. Since $b$ reflects the degree of floating or hardness of a peg in a given country, this explains that the choice of exchange rate regime does not affect the choice of the policy mix anchor. This confirms what we have found in Figure 1, where multiple countries undertake a policy mix disregarding their exchange rate regime. In sum, our model explains that the choice of policy anchor is made separately and not as suggested in the previous literature (see, for instance, Savvides , 1990). Authorities start by choosing the nominal anchor policy according to the country's specificities: the degree of pass-through, money velocity, openness, debt denominated in foreign currency, interest rate and the targeted exchange rate band. The stronger the impacts of openness, velocity, exchange rate pass-through, debt and interest rate, the more likely authorities are to choose a harder peg. Once the nominal anchor is set, authorities choose the real anchor with regards to the degree of trade integration and the degree of intervention on the exchange market. In the next section, we explore whether these domestic fundamentals impact exchange rate stability. 
Figure 2: Policy behavior choices

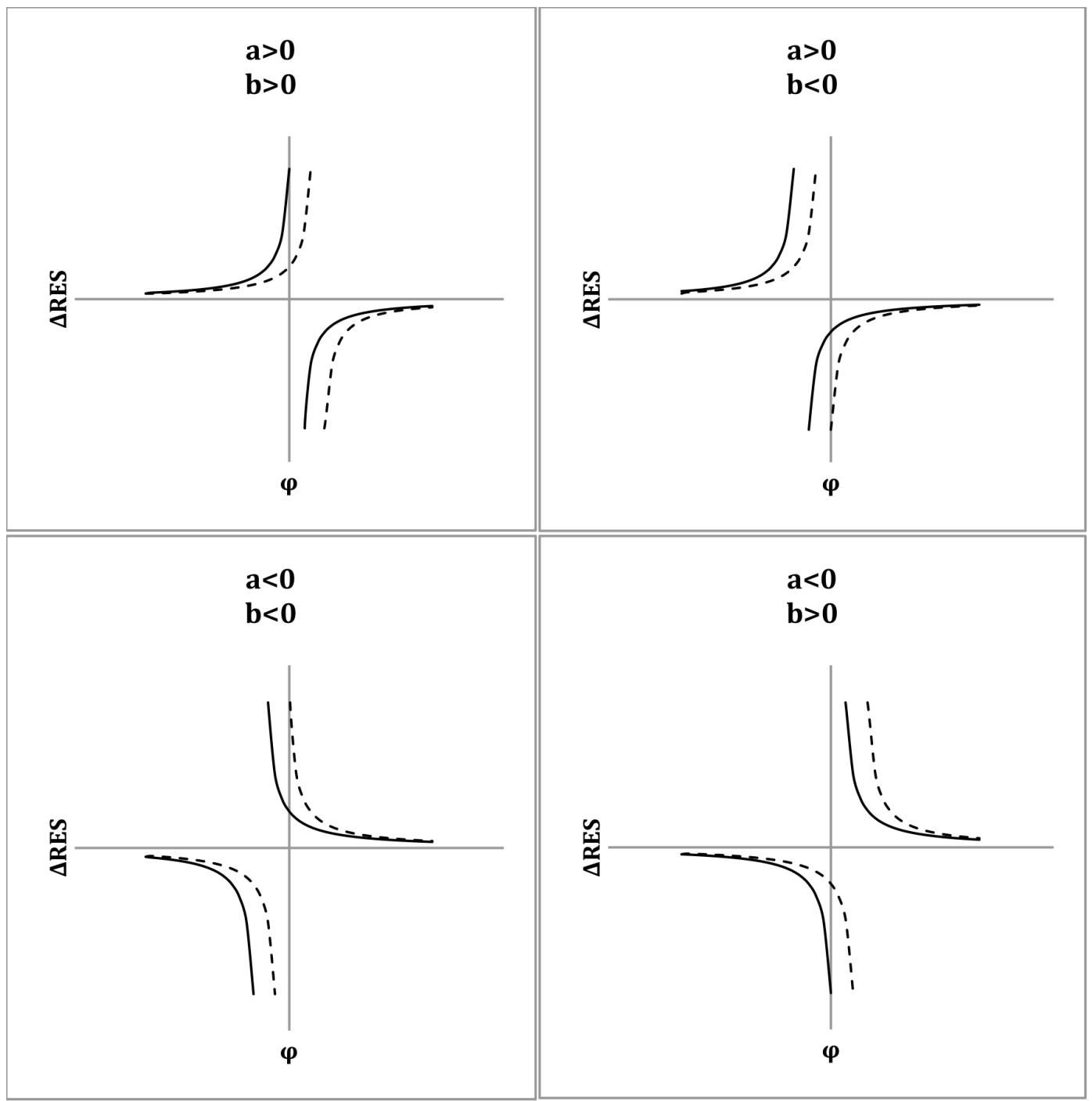




\section{Determinants of SSA currency pegs}

In the last stage, we empirically explore whether the domestic factors that we highlighted in the theoretical model provide incentives for African countries to tighten their nominal pegs. Our aim is to explain the way the African countries peg their currencies. We focus on a sample of 13 African countries: Botswana, Burundi, Cabo Verde, Ethiopia, Ghana, Guinea, Kenya, Liberia, Madagascar, Mauritius, Nigeria, Sierra Leone and South Africa. Our choice is based on data availability and quality. ${ }^{11}$

We consider the following Markov switching (MS) model augmented with a set of economic variables:

$$
\begin{aligned}
\sigma e_{t}^{A F C} & =\alpha_{1}+\gamma_{1}^{1} v e l_{t-1}+\gamma_{1}^{2} d e b_{t-1}+\gamma_{1}^{3} p t_{t-1}+\gamma_{1}^{4} d o_{t-1}+\lambda_{1}^{1} v i x_{t-1}+\lambda_{1}^{2} n e n_{t-1}+\lambda_{1}^{3} e n_{t-1} \lambda_{1}^{4} i_{t-1}+\varepsilon_{t} \text { in state } 1 \\
& =\alpha_{2}+\gamma_{2}^{1} v e l_{t-1}+\gamma_{2}^{2} d e b_{t-1}+\gamma_{2}^{3} p t_{t-1}+\gamma_{2}^{4} d o_{t-1}+\lambda_{2}^{1} v i x_{t-1}+\lambda_{2}^{2} n e n_{t-1}+\lambda_{2}^{3} e n_{t-1} \lambda_{2}^{4} i_{t-1}+\varepsilon_{t} \text { in state } 2 .
\end{aligned}
$$

The estimation procedure is detailed in Appendix (B). The estimates are carried out for the period January 2004November 2016. The dependent variable is defined as the exchange rate volatility between the African currency and the main anchor currency. ${ }^{12}$ Note that the latter corresponds to the currency with the higher estimated weight according to the estimation procedure described in Section 2.2 (in most cases, the US dollar). The factors that are likely to affect the degree of the nominal anchor are divided into domestic and global factors. The variables vel, deb, $p t$, do are the domestic factors and correspond to the velocity of money (computed as the ratio between base money and GDP), the total external debt-to-GDP ratio, the evolving degree of exchange rate pass-through (ERPT), and the evolving degree of trade openness (computed as the ratio between GDP and total trade), respectively. ${ }^{13}$ We take the first difference of these five variables to ensure stationarity. Moreover, all exogenous variables are lagged by one period to avoid endogeneity issues. All data are extracted from the World Bank, IMF DOTS and IMF IFS databases.

Moreover, we control for the effects of global factors: energy and non-energy price volatility (World Bank Commodity Price Data), the CBOE Volatility Index (VIX) and the interest rate differential (computed as the difference between the policy rates of the domestic country and the United States), which are denoted by en, nen, vix and $i$, respectively. We use the log of squared returns of energy and non-energy prices as a proxy for volatility.

We take advantage of the flexible parametric structure of the MS model to allow exchange rate volatility to evolve across two distinct regimes (peggingversusfloating). ${ }^{14}$ Under the condition that $\alpha_{1}<\alpha_{2}$, the first regime is defined by low flexibility against the the anchor currency; the second, by high flexibility. Moreover, the correlation coefficients are regime dependent, implying that the influence of economic factors differ across exchange rate regimes. The main advantage is that this allows us to identify the determinants of the decision to tighten a currency peg. In this view, we need to look

\footnotetext{
${ }^{11}$ We exclude countries belonging to monetary unions, since the degree of exchange rate flexibility is zero.

${ }^{12}$ As a proxy for volatility, we take the log volatility computed as the log of squared returns of the exchange rates.

${ }^{13}$ We estimate a dynamic regression model for the ERPT to African consumer prices. We follow the literature by augmenting the bivariate relationship between the NEER and domestic inflation with trade-weighted foreign prices and domestic real GDP. We take the year-to-year differences of the variables expressed in logarithmic terms. Rolling estimation of the ERPT is performed for each African country over the period from March 1998 to January 2016 with a window size of 72 observations and a step size equal to one. Accordingly, for each African country, we obtain 155 coefficients that represent the dynamic ERPT. The NEER and trade-weighted foreign prices are computed with trade data from the IMF DOTS database. The results, which are not presented here, are available upon request.

${ }^{14}$ We favor time series over panel data for two main reasons. First, we may think that the role of economic determinants can vary from one country to another. Detecting this heterogeneity is important given the prospects for deeper monetary and financial integration in Africa. Second, the MS model allows us to discriminate between two regimes according to different time series properties (here, the mean of the volatility) and to then observe specific schemes or patterns in a given regime.
} 
at which factors are statistically significant in the first regime. For instance, assuming that the coefficients associated with external debt are positive and significant in the first regime implies that an increase in external debt leads to greater exchange rate stability against the anchor currency. Negative coefficients would suggest that a decrease in external debt is associated with a tighter peg. Finally, a non-significant coefficient implies that the variable does not affect exchange rate stability.

The estimations are reported in Tables 3 and 4, and the plots of regime probabilities are shown in Figures 3 and 4 . When the smoothed probability of state 1 is greater than 0.5 , the exchange rate is considered to be in the low flexibility regime (i.e., episodes during which the monetary authority increases exchange rate stability against the USD). First, we compute a likelihood ratio to check whether exchange rate volatility evolves according to a non-linear process. The constrained model is an OLS version of Eq.(25), where all coefficients are linear. The results clearly indicate that exchange rates evolve through two distinct regimes in which the degree of floating differs significantly. This confirms our previous empirical findings of the trade-off between tightening and loosening the nominal currency peg. Moreover, the estimates provide evidence that the influence of the explanatory variables is regime dependent. We find that the constant terms are lower in the first regime (i.e., $\alpha_{1}<\alpha_{2}$ ), implying that regime 1 corresponds to episodes where exchange rate fluctuations against the USD are weaker.

Concerning global factors, we find that non-energy price volatility is significant in regime 1 and positively impacts exchange rate volatility for only four counties (Botswana, Cabo Verde, Ghana and South Africa). This means that higher non-energy price volatility strengthens the incentives of these countries to stabilize their exchange rates against the USD. One explanation is that lower exchange flexibility allows these countries to reduce transaction costs linked to exchange rate fluctuations. Accordingly, increasing exchange rate stability against the USD allows them to preserve revenues for export firms. For other countries, a non-significant effect could be explained by the fact that the commodities they export are under-weighted in the index. ${ }^{15}$ However, we find that energy price index volatility is significant for most of these countries. The negative sign suggests that lower energy price volatility leads to a decrease in exchange rate volatility against the USD. This finding is in line with Cashin et al. (2004), who identify co-movement between world commodity prices and exchange rates among commodity-exporting countries. In the same way, when the VIX volatility index decreases, fluctuations of African currencies against the USD are weaker. In regime 2, we find that the index is positive, implying that during episodes of financial stress, exchange rates become more volatile. For the interest rate differential in regime 1, we find a positive and significant coefficient for all countries except Cabo Verde. A possible explanation for this is that when domestic rates increase faster than US rates, domestic borrowing becomes more costly. This induces a rise in external debt and provides a stronger incentive to stabilize the exchange rate.

\section{INSERT TABLE 3}

Regarding domestic factors, we find that many coefficients are significant in regime 1 but non-significant in regime 2. This is strong evidence that domestic factors are important drivers of exchange rate stability, as suggested by our theoretical results.

\footnotetext{
${ }^{15}$ For instance, more than $36 \%$ of Liberia's exports are composed of iron ore and rubber, but these two commodities represent less than $10 \%$ of the index.
} 
Starting with the external debt-to-GDP ratio, previous studies demonstrate that debt levels would have different effects on countries (see, for instance, Meissner and Oomes, 2009). On the one hand, a large body of literature explains that since these countries are severely indebted, an increase in the debt level would increase debt service payments, which exert pressure on budgetary resources and crowd out domestic investment. This causes a decline in economic growth and puts downward pressure on the currency, which eventually increases the external debt burden. Intuitively, the more liabilities are denominated in a foreign currency, the greater is propensity to peg to that currency. On the other hand, an increase in debt can induce investment productivity, leading to an increase in GDP and currency appreciation. Our results suggest that the first view seems more intuitive in the African context. Indeed, we find that external debt is significant in regime 1 for almost all countries (except Cabo Verde and Sierra Leone). This suggests that any increase in external debt implies that African countries are more likely to peg their currency to the USD. For Burundi, the negative sign can be explained by the fact that external debt has sharply decreased since 2004. This has allowed Burundi to reduce downward pressure on its currency and, thus, reduce exchange rate volatility against the USD.

For the velocity of money, quantitative money theory suggests that any increase in velocity would put some upward pressure on the value of the currency (Agbeyege et al. , 2004; Bleaney and Greenaway , 2001). With an increase of the velocity of money, agents will choose to increase their investments and to spend more on consumption, which will lead to higher economic growth and inflationary pressure. For African countries, the results are mixed, as the velocity of money is significant in about half of the cases. One potential explanation is the greater financial development of some African countries, such as Botswana, South Africa and Cabo Verde (IMF , 2016b). Any increase in the velocity of money would positively impact investments, growth and inflation, which would encourage authorities to contain upward pressure on the exchange rate. The more financially developed the country, the greater the impact.

\section{INSERT TABLE 4}

For the degree of openness indicator, we expect that the more integrated these countries are with the rest of the world, the more they accumulate foreign reserves (for net exporters), thus putting upward pressure on their currencies. In such a case, authorities face a trade-off between letting the currency appreciate to alleviate the external debt burden (at the expense of the real exchange rate and trade competitiveness) and intervening on the foreign exchange market to stabilize the exchange rate. For net importers, the dilemma is reversed. We observe that the degree of openness significantly explains exchange rate stability for all countries except Liberia and South Africa. In the latter cases, this is explained by the high South African exchange rate and its limited foreign exchange intervention. However, a positive and significant coefficient implies that when the degree of openness increases, exchange rate stability increases as well because authorities are more willing to intervene in the foreign exchange market to offset pressure on the domestic currency (Burundi, Cabo Verde, Ethiopia, Ghana, Guinea Kenya and Madagascar). When the sign is negative, any decrease in the degree of openness contributes to increased exchange rate stability without requiring authorities to intervene in the foreign exchange market. This is particularly true for Guinea and Nigeria for which the degree of exchange rate flexibility was found to be large. Finally, a higher degree of ERPT would induce higher imported inflation, thus putting downward pressure on the domestic currency. Accordingly, monetary authorities are more likely to intervene in the foreign exchange market to avoid currency depreciation and an increase in external debt. If trade competitiveness prevails, authorities would let the currency 
depreciate. The latter argument seems consistent for Burundi Ethiopia, Madagascar and Mauritius, since the degree of ERPT does not impact exchange rate stability. A positive sign implies that monetary authorities will tighten their nominal peg when the degree of ERPT increases to contain inflationary pressure (Botswana, Liberia and Nigeria). For the other countries, the degree of ERPT is negatively linked to exchange stability.

\section{Conclusion}

In conclusion, when policymakers choose to anchor the exchange rate it is essential to consider whether they are anchoring real, nominal or both rates. Anchoring the nominal exchange rate occurs by stabilizing variation in reserves in order to 1) respond to current account imbalances, 2) meet foreign liabilities by servicing external debt 3) and maintain access to foreign borrowing. Anchoring the real exchange rate through controls of the nominal exchange rate has the objectives of influencing the consumer trade-off between locally produced and imported goods and promoting external competitiveness. Having a policy mix anchor would satisfy simultaneously these objectives while promoting both internal and external stability.

Our results suggest that states follow a two-step strategy. Policymakers choose their exchange rate regime (nominal target) with regards to the degree of openness, the degree of debt to GDP denominated in foreign currencies and the fluctuation margin band of the exchange rate. Then, authorities choose the real anchor according to the extent of trade integration with the rest of the world and the degree of intervention in the exchange market. The impact of the strategy therefore depends on the behavior of the real anchor with regards to the nominal anchor constrained by the amount of monopolistic power. We find that the strategic behavior of Sub-Saharan African countries is not efficient in terms of reducing external imbalances and that they will always face a trade-off between objectives. The main cause of such behavior is a high degree of monopolistic power that is explained either by diaspora communities controlling some services sectors or institutions controlling their natural resources. To pursue a more efficient strategy in terms of reducing external imbalances, SubSaharan African countries need to create more competitive markets. 
Table 3: Estimates of regime-dependent correlations among exchange rate, domestic and global factors (sample 1)

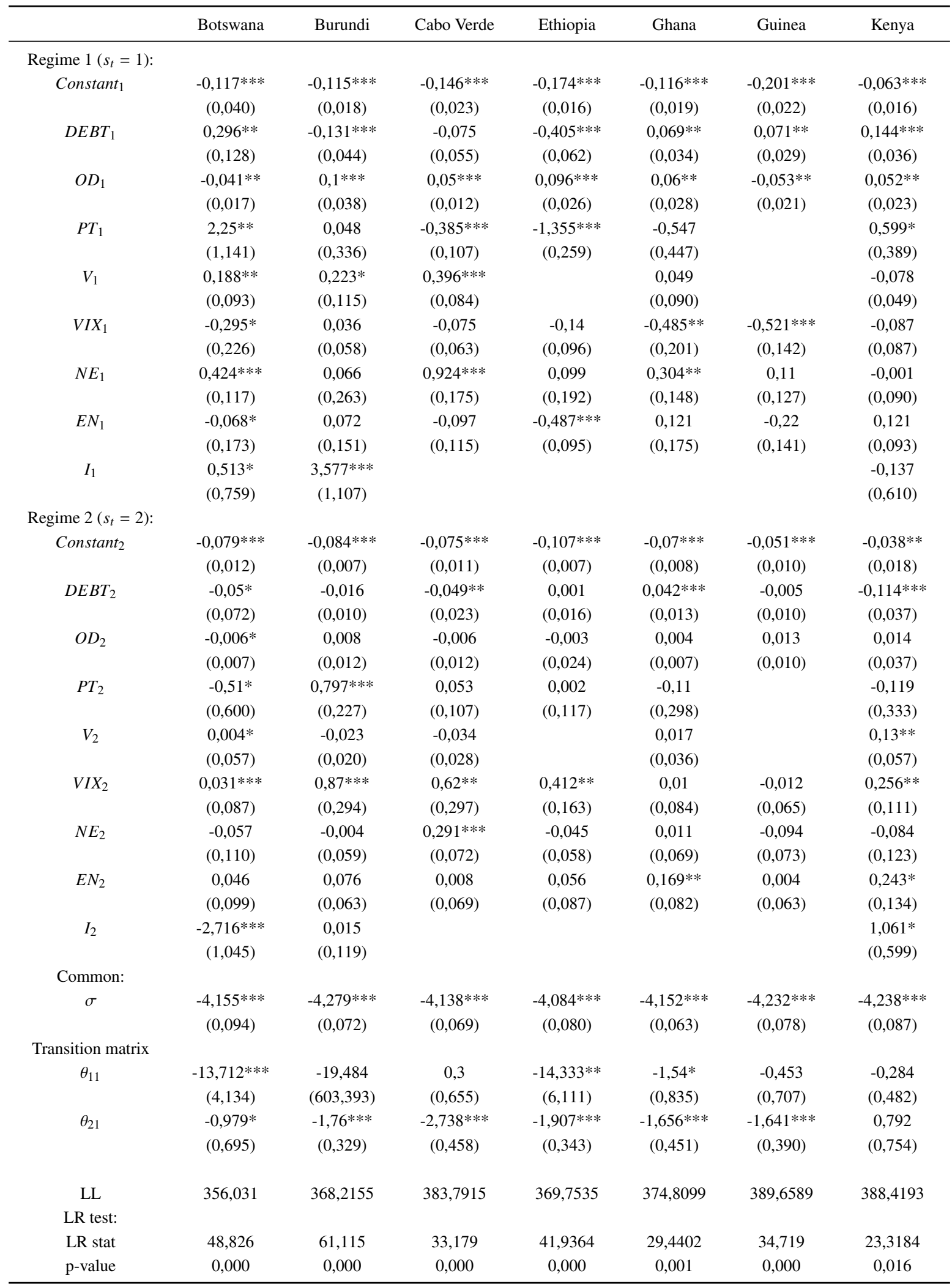

Notes: $*, * *, * * *$ denote significance at the $10 \%, 5 \%$ and $1 \%$ levels, respectively. The standard errors of parameters are reported in parentheses (.), while p-values are displayed in brackets [.]. The LR aims to test whether the Markov switching model outperforms the simple linear regression model. The LR test statistic is computed as follows: $L R=2 \times\left[L L_{M S}(\Theta)-L L_{O L S}(\Theta)\right]$, where $\Theta$ indicates the parameters of the model. The null hypothesis is that the MS model does not fit significantly better than the OLS model. The estimates $D E B T, O D, P T, V, V I X, N E, E N$ and $I$ correspond to the correlations associated with external debt, trade openness, ERPT, velocity of money, VIX, non-energy price index, energy price index, and interest rate differential, respectively. Blank cells indicate that data are not available. 
Table 4: Estimates of regime-dependent correlations among exchange rate, domestic and global factors (sample 2)

\begin{tabular}{|c|c|c|c|c|c|c|}
\hline & Liberia & Madagascar & Mauritius & Nigeria & Sierra Leone & South Africa \\
\hline \multicolumn{7}{|c|}{ Regime $1\left(s_{t}=1\right)$ : } \\
\hline Constant $_{1}$ & $\begin{array}{c}-0,139 * * * \\
(0,019)\end{array}$ & $\begin{array}{c}-0,126^{* * * *} \\
(0,016)\end{array}$ & $\begin{array}{c}-0,133^{* * *} \\
(0,014)\end{array}$ & $\begin{array}{c}-0,143^{* * *} \\
(0,037)\end{array}$ & $\begin{array}{c}-0,207^{* * *} \\
(0,019)\end{array}$ & $\begin{array}{c}-0,129 * * * \\
(0,017)\end{array}$ \\
\hline$D E B T_{1}$ & $\begin{array}{c}0,026 * * * \\
(0,007)\end{array}$ & $\begin{array}{c}0,221 * * * \\
(0,055)\end{array}$ & $\begin{array}{l}-0,027 \\
(0,021)\end{array}$ & $\begin{array}{c}0,568 * * * \\
(0,095)\end{array}$ & $\begin{array}{c}0,008 \\
(0,020)\end{array}$ & $\begin{array}{l}0,109 * \\
(0,060)\end{array}$ \\
\hline$O D_{1}$ & $\begin{array}{l}-0,002 \\
(0,001)\end{array}$ & $\begin{array}{c}0,055 * * * \\
(0,013)\end{array}$ & $\begin{array}{l}-0,033 \\
(0,027)\end{array}$ & $\begin{array}{c}-0,408^{* * *} \\
(0,128)\end{array}$ & $\begin{array}{c}0,02 * \\
(0,011)\end{array}$ & $\begin{array}{c}0,131 \\
(0,096)\end{array}$ \\
\hline$P T_{1}$ & $\begin{array}{c}2,78 \text { *** } \\
(0,992)\end{array}$ & $\begin{array}{c}1,505 \\
(1,276)\end{array}$ & $\begin{array}{c}-0,68 \\
(0,577)\end{array}$ & $\begin{array}{c}3,069 * * * \\
(1,160)\end{array}$ & $\begin{array}{c}-0,168 \text { *** } \\
(0,062)\end{array}$ & $\begin{array}{c}-3,253 * * * \\
(1,172)\end{array}$ \\
\hline$V_{1}$ & & $\begin{array}{l}-0,099 \\
(0,091)\end{array}$ & $\begin{array}{c}0,077 \\
(0,049)\end{array}$ & $\begin{array}{c}0,164 \\
(0,122)\end{array}$ & $\begin{array}{c}0,405 * * * \\
(0,124)\end{array}$ & $\begin{array}{c}0,26 * * * \\
(0,068)\end{array}$ \\
\hline$V I X_{1}$ & $\begin{array}{l}-0,302 \\
(0,202)\end{array}$ & $\begin{array}{c}-0,312 * * * \\
(0,116)\end{array}$ & $\begin{array}{l}-0,021 \\
(0,071)\end{array}$ & $\begin{array}{l}-0,153 \\
(0,175)\end{array}$ & $\begin{array}{l}-0,448 * \\
(0,232)\end{array}$ & $\begin{array}{c}-0,788^{* * *} \\
(0,166)\end{array}$ \\
\hline$N E_{1}$ & $\begin{array}{c}0,237 \\
(0,191)\end{array}$ & $\begin{array}{c}0,157 \\
(0,176)\end{array}$ & $\begin{array}{l}-0,144 \\
(0,138)\end{array}$ & $\begin{array}{c}0,271 \\
(0,460)\end{array}$ & $\begin{array}{l}-0,337 \\
(0,240)\end{array}$ & $\begin{array}{c}0,478 * * * \\
(0,133)\end{array}$ \\
\hline$E N_{1}$ & $\begin{array}{c}-0,542 * * \\
(0,232)\end{array}$ & $\begin{array}{c}-0,212^{* * *} \\
(0,101)\end{array}$ & $\begin{array}{c}-0,192 * * \\
(0,093)\end{array}$ & $\begin{array}{c}-0,527 * * * \\
(0,183)\end{array}$ & $\begin{array}{c}-0,471 * * \\
(0,197)\end{array}$ & $\begin{array}{c}-0,383^{* * *} * \\
(0,124)\end{array}$ \\
\hline$I_{1}$ & $\begin{array}{c}1,134 * * \\
(0,518)\end{array}$ & & $\begin{array}{c}0,938 \\
(0,759)\end{array}$ & $\begin{array}{c}1,82 * * * \\
(0,399)\end{array}$ & $\begin{array}{c}3,621 * * * \\
(1,931)\end{array}$ & \\
\hline \multicolumn{7}{|c|}{ Regime $2\left(s_{t}=2\right)$ : } \\
\hline Constant $_{2}$ & $\begin{array}{c}-0,09 * * * \\
(0,009)\end{array}$ & $\begin{array}{c}-0,082^{* * *} \\
(0,013)\end{array}$ & $\begin{array}{c}-0,095 * * * \\
(0,009)\end{array}$ & $\begin{array}{l}-0,1 * * * \\
(0,010)\end{array}$ & $\begin{array}{c}-0,081 * * * \\
(0,008)\end{array}$ & $\begin{array}{c}-0,071^{* * *} \\
(0,010)\end{array}$ \\
\hline$D E B T_{2}$ & $\begin{array}{l}-0,003 \\
(0,002)\end{array}$ & $\begin{array}{c}0,032 * * * \\
(0,012)\end{array}$ & $\begin{array}{c}0,009 \\
(0,016)\end{array}$ & $\begin{array}{c}0,019 \\
(0,034)\end{array}$ & $\begin{array}{l}-0,02 * \\
(0,011)\end{array}$ & $\begin{array}{c}0,04 \\
(0,039)\end{array}$ \\
\hline$O D_{2}$ & $\begin{array}{c}0,001 \\
(0,001)\end{array}$ & $\begin{array}{c}0,006 \\
(0,013)\end{array}$ & $\begin{array}{c}0,015^{* *} \\
(0,006)\end{array}$ & $\begin{array}{l}-0,001 \\
(0,042)\end{array}$ & $\begin{array}{c}0,013 \\
(0,009)\end{array}$ & $\begin{array}{c}0,013 \\
(0,022)\end{array}$ \\
\hline$P T_{2}$ & $\begin{array}{l}-0,017 \\
(0,190)\end{array}$ & $\begin{array}{c}-1,246^{* * *} \\
(0,610)\end{array}$ & $\begin{array}{l}-0,362 \\
(0,301)\end{array}$ & $\begin{array}{l}-0,498 \\
(0,381)\end{array}$ & $\begin{array}{c}-0,074 * * \\
(0,034)\end{array}$ & $\begin{array}{c}0,465 \\
(0,667)\end{array}$ \\
\hline$V_{2}$ & & $\begin{array}{c}0,066 \\
(0,058)\end{array}$ & $\begin{array}{c}0,039 \\
(0,035)\end{array}$ & $\begin{array}{c}0,007 \\
(0,022)\end{array}$ & $\begin{array}{c}0,004 \\
(0,027)\end{array}$ & $\begin{array}{l}-0,054 \\
(0,075)\end{array}$ \\
\hline$V I X_{2}$ & $\begin{array}{c}0,009 \\
(0,074)\end{array}$ & $\begin{array}{l}-0,003 \\
(0,086)\end{array}$ & $\begin{array}{c}0,362 * * \\
(0,167)\end{array}$ & $\begin{array}{c}0,043 \\
(0,101)\end{array}$ & $\begin{array}{c}0,053 \\
(0,079)\end{array}$ & $\begin{array}{c}0,07 \\
(0,052)\end{array}$ \\
\hline$N E_{2}$ & $\begin{array}{l}-0,018 \\
(0,067)\end{array}$ & $\begin{array}{c}0,048 \\
(0,083)\end{array}$ & $\begin{array}{l}-0,023 \\
(0,075)\end{array}$ & $\begin{array}{l}-0,013 \\
(0,094)\end{array}$ & $\begin{array}{c}0,048 \\
(0,068)\end{array}$ & $\begin{array}{l}-0,045 \\
(0,055)\end{array}$ \\
\hline$E N_{2}$ & $\begin{array}{l}-0,014 \\
(0,069)\end{array}$ & $\begin{array}{l}-0,034 \\
(0,095)\end{array}$ & $\begin{array}{c}0,01 \\
(0,086)\end{array}$ & $\begin{array}{l}-0,055 \\
(0,095)\end{array}$ & $\begin{array}{c}0,006 \\
(0,068)\end{array}$ & $\begin{array}{l}-0,028 \\
(0,055)\end{array}$ \\
\hline$I_{2}$ & $\begin{array}{l}0,601 * \\
(0,364)\end{array}$ & & $\begin{array}{l}-0,081 \\
(0,217)\end{array}$ & $\begin{array}{c}0,317 \\
(0,374)\end{array}$ & $\begin{array}{l}-0,151 \\
(0,614)\end{array}$ & \\
\hline$\sigma$ & $\begin{array}{c}-4,107 * * * \\
(0,062)\end{array}$ & $\begin{array}{c}-4,3 * * * \\
(0,125)\end{array}$ & $\begin{array}{c}-4,172 * * * \\
(0,073)\end{array}$ & $\begin{array}{c}-3,912^{* * *} \\
(0,103)\end{array}$ & $\begin{array}{c}-4,234 * * * \\
(0,068)\end{array}$ & $\begin{array}{c}-4,276^{* * * *} \\
(0,081)\end{array}$ \\
\hline \multicolumn{7}{|c|}{ Transition matrix } \\
\hline$\theta_{11}$ & $\begin{array}{l}-0,288 \\
(0,919)\end{array}$ & $\begin{array}{l}-0,455 \\
(0,703)\end{array}$ & $\begin{array}{c}1,487 * * * \\
(0,487)\end{array}$ & $\begin{array}{l}-1,932 \\
(2,459)\end{array}$ & $\begin{array}{l}-0,905 \\
(0,777)\end{array}$ & $\begin{array}{c}-14,83^{* * *} \\
(1,241)\end{array}$ \\
\hline$\theta_{21}$ & $\begin{array}{c}-2,275^{* * *} \\
(0,555)\end{array}$ & $\begin{array}{c}-1,543^{* * *} \\
(0,518)\end{array}$ & $\begin{array}{c}-2,266^{* * *} \\
(0,463)\end{array}$ & $\begin{array}{c}-1,969 * * * \\
(0,629)\end{array}$ & $\begin{array}{c}-1,661 * * * \\
(0,424)\end{array}$ & $\begin{array}{c}-2,026^{* * *} \\
(0,628)\end{array}$ \\
\hline LL & 382,9178 & 337,9535 & 370,0355 & 353,8701 & 389,0437 & 404,5098 \\
\hline \multicolumn{7}{|l|}{ LR test: } \\
\hline LR stat & 19,0112 & 33,9408 & 39,6462 & 36,727 & 37,6158 & 26,6028 \\
\hline p-value & 0,040 & 0,000 & 0,000 & 0,000 & 0,000 & 0,003 \\
\hline
\end{tabular}

Notes: $* * *, * * *$ denote significance at the $10 \%, 5 \%$ and $1 \%$ levels, respectively. The standard errors of parameters are reported in parentheses (.), while the p-values are displayed in brackets [.]. The LR aims to test whether the Markov switching model outperforms the simple linear regression model. The LR test statistic is computed as follows: $L R=$ $2 \times\left[L L_{M S}(\Theta)-L L_{O L S}(\Theta)\right]$, where $\Theta$ indicates the parameters of the model. The null hypothesis is that the MS model does not fit significantly better than the OLS model. The estimates DEBT, OD, PT, V,VIX, NE, EN and $I$ correspond to correlations associated with external debt, trade openness, ERPT, velocity of money, VIX, non-energy price index, energy price index, and interest rate differential, respectively. Blank cells indicate that data are not available. 
Figure 3: Smooth probabilities of being in the low-volatility regime (sample 1)
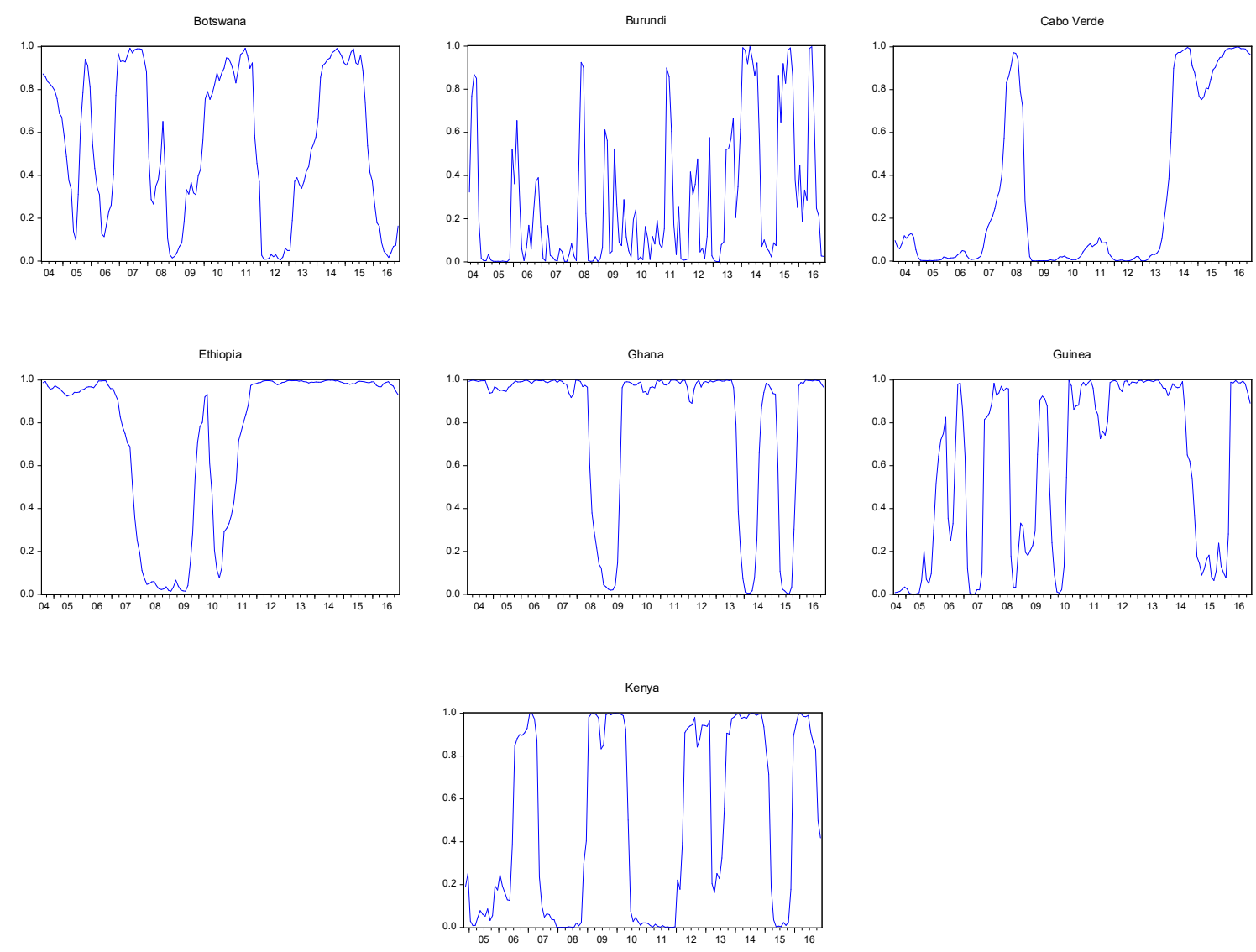

Figure 4: Smooth probabilities of being in the low-volatility regime (sample 2)
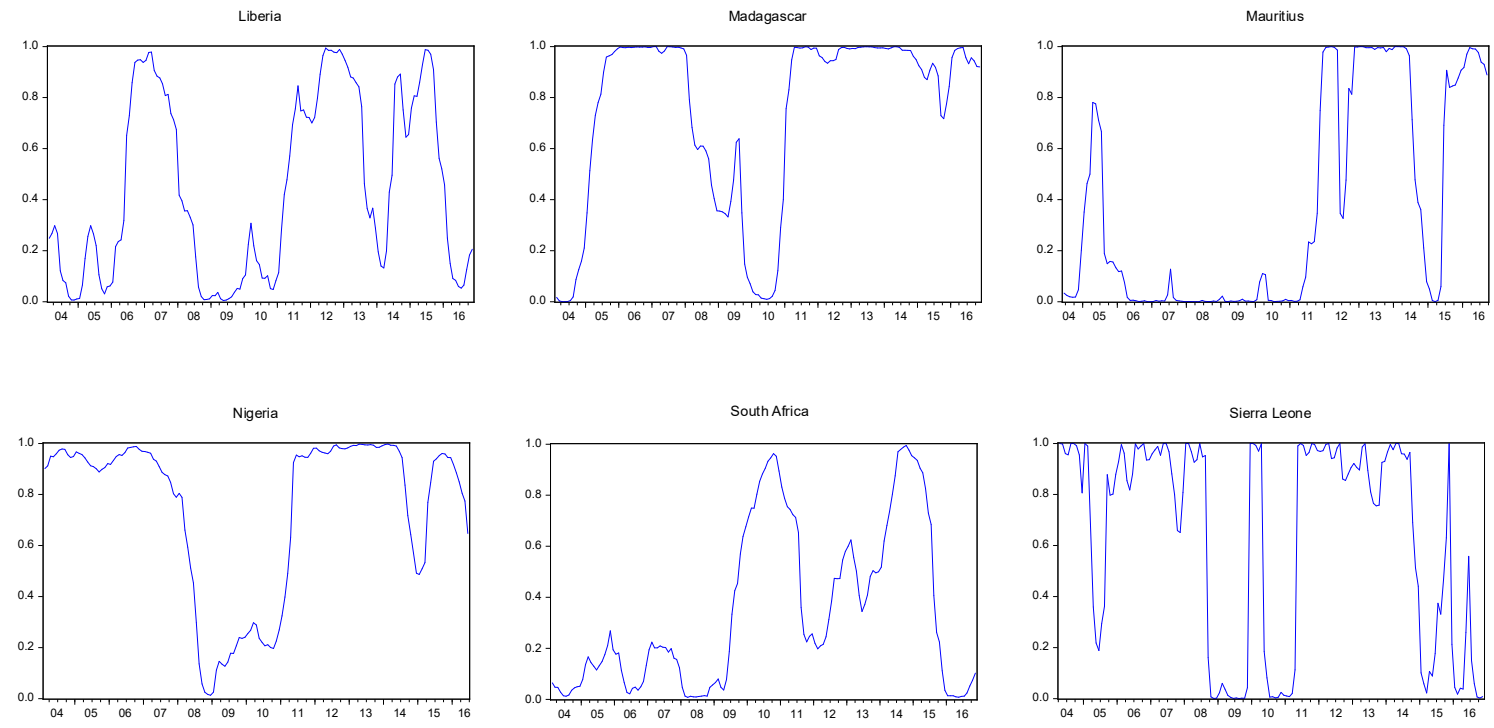


\section{Appendix A: Solving for nominal and real exchange rates}

The export sector is an enclave in the sense that the domestic country is assumed to export minerals, natural resources, oil, cocoa, coffee, etc., directly to foreign countries. Equilibrium in the non-tradable and tradable markets implies that $Y_{N t}=C_{N t}, Y_{T t}=C_{T t}$. Using one of these equalities and the expressions in (6), one finds the following expression of the real exchange rate:

$$
\varphi_{t}=\frac{(1-\alpha)}{\alpha} \frac{1}{\left(1+r_{t}\right)}\left(\frac{Y_{t}}{Y_{N t}}\right)+1-\alpha=\frac{P_{N t}}{\left(1+\mu_{t}\right) \bar{e}_{t} P_{M t}}, \mu_{t}=\frac{-\alpha}{\gamma} \varphi_{t} Y_{N t}
$$

or

$$
\varphi_{t}=\frac{w_{t}}{\bar{e}_{t} P_{M t} \frac{1-\alpha}{\gamma} \frac{1}{1+r_{t}}\left(Y_{t}-Y_{N t}\right)},
$$

with $\bar{e}_{t}=\lambda_{1} e_{t}^{u s}+\lambda_{2} e_{t}^{e u r o}+\widetilde{\lambda}_{t}$ and $r_{t}=r_{t}^{u s}+\left(E_{t} e_{t+1}^{u s}-e_{t}^{u s}\right)+\xi_{t}$. Moreover, from Eq. 13, we obtain

$$
\bar{e}_{t}=\frac{\Delta R E S_{t}+P_{X t} X_{t}+\bar{e}_{t+1}^{a} B_{t+1}}{r_{t} B_{t}+\left[1-\left(\frac{\alpha}{\gamma}\right) \varphi_{t} Y_{N t}\right] P_{M t} Y_{T t}}
$$

where (using the consumer's budget constraint and Eqs. (6) and (7) to compute the demand for money):

$$
\begin{aligned}
\bar{e}_{t+1}^{a} B_{t+1} & =\left(1+r_{t}\right) \bar{e}_{t} B_{t}-\frac{1}{1+r_{t}}\left\{\left(P_{t} Y_{t}-\left(m_{t+1}\right)-m_{t}\right)\right\} \\
- & \frac{1}{\left(1+r_{t}\right)}\left\{w_{t} Y_{N t}-P_{X t} X_{t}+\left[\left(\frac{\alpha}{\gamma}\right) \varphi_{t} Y_{N t} Y_{T t}\right]\right\}, \\
m_{t}= & \frac{(1-\alpha) P_{t} Y_{t}}{\left(1+r_{t}\right)}, P_{t} Y_{t}=P_{T t} Y_{T t}+P_{N t} Y_{N t} .
\end{aligned}
$$

Changes in foreign reserves are given by the money supply equation:

$$
\Delta R E S_{t}=-\theta_{1}\left(\bar{e}_{t}-\lambda_{1} e_{t}^{u s}-\left(1-\lambda_{1}\right) e_{t}^{e u r o}\right)+\Delta L_{t}+\Delta U_{t} .
$$

Solving the system of equations, our steady state is:

$$
\begin{gathered}
\bar{e}_{t}=\frac{\left.-\left[\frac{-\alpha w_{t} Y_{N_{t}} Y_{T_{t}}}{\left(1+r_{t}\right)}-\left(1+\frac{1}{\left(1+r_{t}\right)}\right) P_{X_{t}} X_{t}+\frac{1}{\left(1+r_{t} t\right.}\left(1+\frac{1-\alpha}{\left(1+r_{t}\right)}\right)\right) P_{N t} Y_{N_{t}}+m_{t+1}-w_{t} Y_{N_{t}}-\theta_{1}\left[\lambda \lambda_{1} e_{t}^{u s}+\left(1-\lambda_{1}\right) e_{t}^{e a r r}\right]-\Delta L_{t}-\Delta U_{t}\right]}{2\left[\left(\theta_{1}-B_{t}\right)+P_{M t} Y_{T_{t}}\left(1-Y_{N t}\right)(1+a b)\right]}, \\
\bar{e}_{t+1}^{a} B_{t+1}=\left(1+r_{t}\right) \bar{e}_{t} B_{t}-\frac{1}{1+r_{t}}\{\} P_{N t} Y_{N t}\left(1+\frac{(1-\alpha)}{\left.\left(1+r_{t}\right)\right)}-m_{t+1}+w_{t} Y_{N t}\right. \\
-P_{X t} X_{t}+\left[\left(\frac{\alpha}{\gamma}\right) \varphi_{t} Y_{N t} Y_{T t}\right]+\left(1-\left(\frac{\alpha}{\gamma}\right) \varphi_{t} Y_{N t}\right) \bar{e}_{t} P_{M t}\left(1+\frac{(1-\alpha)}{\left(1+r_{t}\right)}\right) .
\end{gathered}
$$


Solving Eqs. (26b), (27) and (29) through Eq. (31), we obtain:

$$
\begin{aligned}
& \bar{e}_{t}^{2}\left[\left(\theta_{1}-B_{t}\right)+P_{M t} Y_{T t}\left(1-Y_{N t}\right)\left(1+\frac{1}{1+r_{t}}\left(1+\frac{(1-\alpha)}{\left(1+r_{t}\right)}\right)\right]\right. \\
& +\bar{e}_{t}\left[\frac{-\alpha w_{t} Y_{N t} Y_{T t}}{\left(\frac{(1-\alpha)}{\left(1+r_{t}\right)}\right)\left(Y_{t}-Y_{N t}\right)}-\left(1+\frac{1}{1+r_{t}}\right) P_{X t} X_{t}+\frac{1}{1+r_{t}}\left(1+\frac{(1-\alpha)}{\left(1+r_{t}\right)}\right) P_{N t} Y_{N t}\right. \\
& \left.+m_{t+1}-w_{t} Y_{N t}-\theta_{1}\left[\lambda_{1} e_{t}^{u s}+\left(1-\lambda_{1}\right) e_{t}^{\text {euro }}\right]-\Delta L_{t}-\Delta U_{t}\right] \\
& +\frac{w_{t} Y_{N t} Y_{T t}}{\left(P_{M t} \frac{(1-\alpha)}{\left(1+r_{t}\right)}\left(Y_{t}-Y_{N t}\right)\right.}=0 .
\end{aligned}
$$

Setting:

$$
a=\frac{1}{1+r_{t}}, b=\left(1+\frac{1-\alpha}{1+r_{t}}\right)
$$

and assuming that the discriminant is null, we have

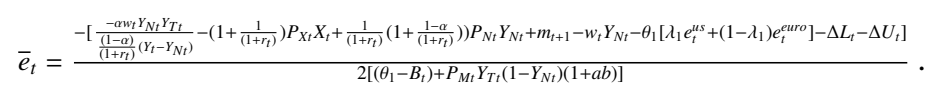

\section{Defining:}

$$
\begin{aligned}
& A_{t}=\frac{\alpha w_{t} Y_{N t} Y_{T t}}{a(1-\alpha)\left(Y_{t}-Y_{N t}\right)}+(1+a) P_{X t} X_{t}+(1-a b) P_{N t} Y_{N t}-m_{t+1}+\overline{X_{t}} \\
& C_{t}=B_{t}+P_{M t} Y_{T t}\left(1-Y_{N t}\right)(1+a b),
\end{aligned}
$$

We rewrite

$$
\bar{e}_{t}=\frac{A_{t}+\theta_{1}\left[\lambda_{1} e_{t}^{u s}+\left(1-\lambda_{1}\right) e_{t}^{e u r o}\right]}{\left(\theta_{1}-C_{t}\right)}
$$

Setting:

$$
D_{t}=\frac{w_{t}}{P_{M t}\left\{\frac{(1-\alpha)}{\gamma} a\left(Y_{t}-Y_{N t}\right)\right\}}
$$

We obtain:

$$
\varphi_{t}=D_{t}\left(\frac{1}{\overline{e_{t}}}\right)=\frac{D_{t}\left[\theta_{1}-\overline{C_{t}}\right]}{A_{t}+\theta_{1}\left[\lambda_{1} e_{t}^{u s}+\left(1-\lambda_{1}\right) e_{t}^{\text {euro }}\right]}
$$

With:

$$
\overline{X_{t}}=2\left(\Delta L_{t}+\Delta U_{t}\right)
$$


We have:

$$
\Delta R E S_{t}=\frac{\theta_{1}\left[A_{t}+\overline{C_{t}} \lambda_{1} e_{t}^{u s}+\left(1-\lambda_{1}\right) \overline{C_{t}} e_{t}^{\text {euro }}\right]+\overline{X_{t}}\left[\theta_{1}-\overline{C_{t}}\right]}{\left[\theta_{1}-\overline{C_{t}}\right]} .
$$




\section{Appendix B}

This appendix briefly details the estimation procedure for the general Markov switching model. The maximum likelihood method is employed to provide estimates of the parameters, and the BFGS algorithm is used to perform non-linear optimization.

The parameters of Eq. (25) depend upon a hidden variable $s_{t} \in\{1,2\}$ representing a particular state of exchange rate volatility. Since the states are unobservable, the inference of $s_{t}$ takes the form of a probability given observations on $\sigma e_{t}^{A F C}$. The state-generating process is an ergodic two-regime Markov chain of order 1 with the following transition probabilities:

$$
P_{i j}=\operatorname{Pr}\left(s_{t}=i \mid s_{t-1}=j\right), \sum_{i=1}^{2} p_{i j}=1, \text { for all } i, j \in\{1,2\}
$$

with,

$$
p_{11}=\frac{\exp \left(\theta_{1}\right)}{1+\exp \left(\theta_{1}\right)}, \quad p_{22}=\frac{\exp \left(\theta_{2}\right)}{1+\exp \left(\theta_{2}\right)}
$$

The conditional likelihood function for the observed data is defined as:

$$
\begin{aligned}
L(\Theta) & =\prod_{t=1}^{T} \sum_{i=1}^{2} \sum_{j=1}^{2} f\left(y_{t} \mid s_{t}=i, s_{t-1}=j, \Omega_{t}, \xi_{t-1} ; \Theta\right) \times \mathbb{P}\left(s_{t}=i, s_{t-1}=j \mid \Omega_{t}, \xi_{t-1} ; \Theta\right) \\
& =\sum_{t=1}^{T} \ln f\left(y_{t} \mid \Omega_{t}, \xi_{t-1} ; \Theta\right)
\end{aligned}
$$

where $\xi_{t}=\left(y_{t}, y_{t-1}, \ldots, y_{1}\right), \Omega_{t}=\left(X_{t}^{\prime}, X_{t-1}^{\prime}, \ldots, X_{1}^{\prime}\right)$ denotes the vector containing observations through date $t$, and $\Theta_{t}$ is the vector of model parameters. Considering the normality assumption, the regime-dependent densities are defined as:

$$
\begin{aligned}
& f\left(y_{t} \mid s_{t}=1, s_{t-1}=j, \Omega_{t}, \xi_{t-1} ; \Theta\right)=\frac{\phi\left(\frac{\left(y_{t}-\alpha_{1}-\beta_{1} X_{t}^{\prime}\right)}{\sigma}\right)}{\sigma P_{1 j}\left(z_{t}\right)}, \\
& f\left(y_{t} \mid s_{t}=2, s_{t-1}=j, \Omega_{t}, \xi_{t-1} ; \Theta\right)=\frac{\phi\left(\frac{\left(y_{t}-\alpha_{2}-\beta_{2} X_{t}^{\prime}\right)}{\sigma}\right)}{\sigma P_{2 j}\left(z_{t}\right)},
\end{aligned}
$$

where $\Phi$ is the standard logistic cumulative distribution function and $\phi$ is the standard normal probability density function. The model is estimated using a maximum likelihood estimator for mixtures of Gaussian distributions, which provides efficient and consistent estimates under the normality assumption (see, e.g., Kim et al. , 2008). Applying Bayes' rule, the 
weighting probabilities are computed recursively:

$$
\begin{aligned}
\mathbb{P}\left(s_{t}=i, s_{t-1}=j \mid \Omega_{t}, \xi_{t-1} ; \Theta\right) & =\mathbb{P}\left(s_{t}=i, s_{t-1}=j \mid z_{t} ; \Theta\right) \mathbb{P}\left(s_{t-1}=j \mid \Omega_{t}, \xi_{t-1} ; \Theta\right) \\
& =P_{i j}\left(z_{t}\right) \mathbb{P}\left(s_{t-1}=j \mid \Omega_{t}, \xi_{t-1} ; \Theta\right), \\
\mathbb{P}\left(s_{t}=i \mid \Omega_{t+1}, \xi_{t} ; \Theta\right) & =\frac{\sum_{j} f\left(y_{t} \mid s_{t}=i, s_{t-1}=j, \Omega_{t}, \xi_{t-1} ; \Theta\right) \mathbb{P}\left(s_{t}=i, s_{t-1}=j \mid \Omega_{t}, \xi_{t-1} ; \Theta\right)}{f\left(y_{t} \mid \Omega_{t}, \xi_{t-1} ; \Theta\right)} .
\end{aligned}
$$




\section{References}

Agbeyegbe, T.D., Stotsky, J., WoldeMariam, A., 2006. Trade liberalization, exchange rate changes, and tax revenue in Sub-Saharan Africa. Journal of Asian Economics, 17, 261-284

Allen, F., Giovannetti, G., 2011. The Effects of the financial crisis on Sub-Saharan Africa. Review of Development Finance, 1, 1-27.

Bleaney, M., Greenaway, D., 2001. The impact of terms of trade and real exchange rate volatility on investment and growth in subSaharan Africa. Journal of Development Economics, 65, 491-500.

Calvo, G.A. and Mishkin, F.S., 2003. The mirage of exchange rate regimes for emerging market countries. The Journal of Economic Perspectives, 17, 99-118.

Calvo, G.A., Reinhart, C.M., and Vegh, C.A., 1995. Targeting the real exchange rate: theory and evidence. Journal of Development Economics, 47, 97-133.

Cashin, P., Céspedes, L., Sahay, R., 2004. Commodity currencies and the real exchange rate. Journal of Development Economics, 75 , $239-268$

Chan, Y., Rogoff, K., 2003. Commodity currencies. Journal of International Economics, 60, 133-160.

Frankel, J.A., and Wei, S.J., 1994. Yen bloc or dollar bloc? Exchange rate policies of the East Asian economies. In: Ito, T., Krueger, A. (Eds.), Macroeconomic Linkages: Savings, Exchange Rates and Capital Flows. Chicago: University of Chicago Press, 295-329.

Frankel, J., Wei, S.-J., 2007. Assessing China's exchange rate regime. Economic Policy 22, 575-627.

Gervais, O., Schembri, L., Suchanek, L., 2016. Current account dynamics, real exchange rate adjustment, and the exchange rate regime in emerging-market economies. Journal of Development Economics, 119, 86-99.

Gnimassoun, B., 2015. The importance of the exchange rate regime in limiting current account imbalances in Sub-Saharan African countries. Journal of International Money and Finance, 53, 36-74.

Harrigan, J., 2006. Time to Exchange the Exchange-Rate Regime: Are Hard Pegs the Best Option for Low-Income Countries? Development Policy Review, 24, 205-223.

Husain, A.M., Mody, A., and Rogoff, K.S., 2005. Exchange rate regime durability and performance in developing versus advanced economies. Journal of Monetary Economics, 52, 35-64.

Hooper, P., Morton, J., 1982. Fluctuations in the dollar: A model of nominal and real exchange rate determination. Journal of International Money and Finance, 1, 39-56.

International Monetary Fund, 2016. Annual Report on Exchange Arrangements and Exchange Restrictions (Washington: International Monetary Fund. October 2016).

International Monetary Fund, 2016. Financial Development in Sub-Saharan Africa: Promoting Inclusive and Sustainable Growth. IMF staff papers (Washington: International Monetary Fund. September 2016).

Iwanow, T., KirkPatrick, C., 2009. Trade Facilitation and Manufactured Exports: Is Africa Different? World Development, 37, 10391050

Kim, C.-J., Piger, J., Startz, R., 2008. Estimation of Markov regime-switching regression models with endogenous switching. Journal of Econometrics 143, 263-273.

Krippner, L., 2013. Measuring the stance of monetary policy in zero lower bound environments. Economic Letters 118, 135-138.

Meissner, C., Oomes, N., 2009. Why do countries peg the way they peg? The determinants of anchor currency choice. Journal of International Money and Finance, 28, 522-547.

Nicita, A., Rollo, V., 2014. Market access conditions and Sub-Saharan Africa's exports diversification. World Development, 68, 254263

Pina, G., 2015. The recent growth of international reserves in developing economies: A monetary perspectives. Journal of International 
Money and Finance, 58, 172-190.

Qureshi, M.S., Tsangarides, C.G., 2012. Hard or soft pegs? Choice of exchange rate regime and trade in Africa. World Development, 40, 667-680.

Savvides, A., 1990. Real exchange rate variability and the choice of exchange rate regime by developing countries. Journal of International Money and Finance, 9, 440-454.

Staveley-O'Carroll, J., Staveley-O'Carroll, O., 2017. Exchange rate targeting in presence of foreign debt obligations. Journal of Macroeconomics (in press) doi:10.1016/j.jmacro.2017.12.005.

Thomas, A., 2012. Exchange rate and foreign interest rate linkages for Sub-Saharan Africa floaters. IMF Working Paper 12/208 (Washington: International Monetary Fund. August 2012).

United Nations Conference on Trade and Development, 2016. Trade and Current Account Balances in Sub-Saharan Africa: Stylized Facts and Implications for Poverty (New York, 2016)

United Nations Conference on Trade and Development, 2016. Economic Development in Africa: Debt Dynamics and Development Finance in Africa. United Nations (New York, 2016). .

von Hagen, J., and Zhou, J., 2007. The choice of exchange rate regimes in developing countries: a multinomial panel analysis. Journal of International Money and Finance, 26, 1071-1094. 